\title{
Molecular Docking and Biophysical Studies for Antiproliferative Assessment of Synthetic Pyrazolo-Pyrimidinones Tethered with Hydrazide-Hydrazones
}

\author{
Mabrouk Horchani ${ }^{1, \dagger}$, Gerardo Della Sala ${ }^{2,3,+}{ }^{\mathbb{D}}$, , Alessia Caso ${ }^{4}{ }^{\mathbb{D}}$, Federica $D^{\prime}$ Aria $^{5}$, Germana Esposito ${ }^{4} \mathbb{D}^{\mathbb{D}}$, \\ Ilaria Laurenzana ${ }^{3}{ }^{-}$, Concetta Giancola ${ }^{5} \mathbb{D}$, Valeria Costantino ${ }^{4, *} \mathbb{D}$, Hichem Ben Jannet ${ }^{1, *}$ and Anis Romdhane ${ }^{1}$ \\ 1 Laboratory of Heterocyclic Chemistry, Natural Products and Reactivity, Medicinal Chemistry and Natural \\ Products (LR11ES39), Faculty of Sciences of Monastir, University of Monastir, 5000 Monastir, Tunisia; \\ horchani.mabrouk@gmail.com (M.H.); anis_romdhane@yahoo.fr (A.R.) \\ 2 Department of Marine Biotechnology, Stazione Zoologica Anton Dohrn, Villa Comunale, 80125 Naples, Italy; \\ gerardo.dellasala@unina.it \\ 3 Laboratory of Pre-Clinical and Translational Research, IRCCS-CROB, Referral Cancer Center of Basilicata, \\ 85028 Rionero in Vulture, Italy; ilaria.laurenzana@crob.it \\ 4 The Blue Chemistry Lab, Department of Pharmacy, University of Naples Federico II, Via D. Montesano 49 \\ 80131 Naples, Italy; alessia.caso@unina.it (A.C.); germana.esposito@unina.it (G.E.) \\ 5 Department of Pharmacy, University of Naples Federico II, Via D. Montesano 49, 80131 Naples, Italy; \\ federica.daria@unina.it (F.D.); giancola@unina.it (C.G.) \\ * Correspondence: valeria.costantino@unina.it (V.C.); hichem.bjannet@gmail.com (H.B.J.) \\ + These authors contributed equally to this work.
}

Citation: Horchani, M.; Della Sala, G.; Caso, A.; D'Aria, F.; Esposito, G.; Laurenzana, I.; Giancola, C.; Costantino, V.; Jannet, H.B. Romdhane, A. Molecular Docking and Biophysical Studies for Antiproliferative Assessment of Synthetic Pyrazolo-Pyrimidinones Tethered with Hydrazide-Hydrazones. Int. J. Mol. Sci. 2021, 22, 2742. https://doi.org/10.3390/ijms22052742

Academic Editor: Silvie Rimpelova

Received: 17 February 2021

Accepted: 3 March 2021

Published: 8 March 2021

Publisher's Note: MDPI stays neutra with regard to jurisdictional claims in published maps and institutional affiliations.

Copyright: (c) 2021 by the authors Licensee MDPI, Basel, Switzerland. This article is an open access article distributed under the terms and conditions of the Creative Commons Attribution (CC BY) license (https:// creativecommons.org/licenses/by/ $4.0 /)$.
Abstract: Chemotherapy represents the most applied approach to cancer treatment. Owing to the frequent onset of chemoresistance and tumor relapses, there is an urgent need to discover novel and more effective anticancer drugs. In the search for therapeutic alternatives to treat the cancer disease, a series of hybrid pyrazolo[3,4- $d$ ]pyrimidin-4(5H)-ones tethered with hydrazide-hydrazones, $\mathbf{5 a}-\mathbf{h}$, was synthesized from condensation reaction of pyrazolopyrimidinone-hydrazide 4 with a series of arylaldehydes in ethanol, in acid catalysis. In vitro assessment of antiproliferative effects against MCF-7 breast cancer cells, unveiled that $\mathbf{5 a}, \mathbf{5 e}, \mathbf{5 g}$, and $\mathbf{5 h}$ were the most effective compounds of the series and exerted their cytotoxic activity through apoptosis induction and G0/G1 phase cell-cycle arrest. To explore their mechanism at a molecular level, 5a, 5e, 5g, and $5 \mathrm{~h}$ were evaluated for their binding interactions with two well-known anticancer targets, namely the epidermal growth factor receptor (EGFR) and the G-quadruplex DNA structures. Molecular docking simulations highlighted high binding affinity of $\mathbf{5 a}, \mathbf{5 e}, \mathbf{5} \mathbf{g}$, and $\mathbf{5 h}$ towards EGFR. Circular dichroism (CD) experiments suggested $\mathbf{5 a}$ as a stabilizer agent of the G-quadruplex from the Kirsten ras (KRAS) oncogene promoter. In the light of these findings, we propose the pyrazolo-pyrimidinone scaffold bearing a hydrazide-hydrazone moiety as a lead skeleton for designing novel anticancer compounds.

Keywords: pyrazolopyrimidinone; hydrazide-hydrazone; antitumor lead compound; cytotoxic activity; antiproliferative activity; molecular docking; epidermal growth factor receptor; G-quadruplex DNA; KRAS; circular dichroism

\section{Introduction}

Cancer is a main health issue worldwide due to the yearly increases in the number of patients with this real disease [1]. According to the World Health Organization (WHO), cancer cases, which were discovered in 2012, surpassed 14 million, and it is expected to reach 22 million in 2030 [2]. Discovery of new anticancer drug candidates is extremely challenging, mainly due to the metabolic heterogeneity and molecular complexity of tumors [3], as well as to the onset of chemoresistance mechanisms and tumor relapses. In the last few years, faced with the urgent need for new drug launches, our research group has 
explored both natural products inspired synthesis and chemical modification of synthetic small molecules for antitumor lead identification $[4,5]$. Although natural products are a reservoir of bioactive scaffolds [6-11], synthesis of small molecules represents a powerful and effective strategy to provide novel chemical entities for cancer therapy, primarily for their easy availability. Notably, fragment-based lead discovery approaches together with building block analysis of approved drugs has provided useful hints in designing drug-like compounds in medicinal chemistry [12,13]. In addition, integration of cell-based and/or cell-free bioassays and in silico molecular docking allows, at an early stage, filtering out of molecules lacking any biological effects.

In this light, and as known, heterocyclic compounds occupy a pivotal position in modern medicinal chemistry. More especially, nitrogenous cyclic moieties play a vital role in the synthesis of potent biomolecules.

Indeed, pyrazoles are reported to exhibit cytotoxic [14], anti-inflammatory [15], anti$\mathrm{HCV}$, and antitumor activity [16]. Furthermore, pyrimidinone derivatives constitute a promising versatile class of heterocyclic compounds, which recently attracted much interest from chemists due to their outstanding potential, such as insecticide [17], antityrosinase [18], antimicrobial [19], and anticancer agents [20]. Pyrazole-fused pyrimidinones are considered as the most ubiquitous heterocyclic privileged scaffolds and these moieties are present in a variety of potent therapeutic compounds with different pharmacological properties, such as antioxidant [21], antituberculosis [22], cardiovascular [23], antimicrobial [24], anticancer [25], and cytotoxic activities (Figure 1) [26-28].<smiles>COc1cc(OC)cc(C2=NCCC(=O)N2)c1</smiles>

$\mathrm{D}$<smiles>COc1cc(/C=N/n2c(C)nc3c(cnn3-c3ccc(Cl)cc3)c2=O)cc(OC)c1OC</smiles><smiles>O=C(CSC1=NC2CC3CC(C2)CC1C3)N/N=C1/C(=O)Nc2ccc(F)cc21</smiles>

E

Figure 1. Previously reported cytotoxic compounds: pyrazole-fused pyrimidinones (A-C); hydrazide-hydrazones linked to either pyrazole (D) or pyrimidine (E). 
On another hand, the pharmacophore ingredient with $\mathrm{CO}-\mathrm{NH}-\mathrm{N}=\mathrm{CH}$ (hydrazidehydrazones) has received considerable attention due to its broad spectrum of biological applications. Thus, hydrazide-hydrazones are known as anti-diabetic [29], antileishmanial [30], antimalarial [31], and anti-tumor compounds [32]. Hydrazide-hydrazones linked to heterocyclic moiety as pyrazole or pyrimidine are known to have a significant cytotoxic potential, as in the case of molecules D and E in Figure 1 [33,34].

In view of the above-mentioned findings, and in the search for therapeutic alternatives to treat the cancer disease, we designed the synthesis of novel hybrid conjugates through combination of two distinct cytotoxic pharmacophores, namely the pyrazolo-pyrimidinone and the hydrazide-hydrazone motifs. A small library of twelve molecules was generated and evaluated for its anticancer potential in the human breast adenocarcinoma MCF-7 cell line, to select the most potent lead compounds for mechanism-of-action and targetidentification studies. MCF-7 cells were used as a model in our screening, as breast cancer, together with lung cancer, was the most common cancer worldwide in 2018, according to WHO estimates [2].

Particularly, in a lead optimization perspective, this novel pyrazolo-pyrimidinone scaffold bearing a hydrazide-hydrazone moiety, was probed for its ability to (1) interact with the epidermal growth factor receptor (EGFR) tyrosine kinase and (2) stabilize G-quadruplex DNA structures, currently known as anticancer targets for cancer therapy [35-37].

EGFR is a membrane receptor overexpressed in many solid tumors, including breast, ovarian, head-and-neck, renal, prostate, colon, pancreas, and non-small-cell lung cancer [38]. EGFR is a member of the ErbB family (originally named because of their homology to the erythroblastoma viral gene product, v-erbB) of structurally related receptor tyrosine kinases (RTKs) and controls downstream signaling pathways, inducing cell growth, cell cycle progression, angiogenesis, cell motility and apoptosis inhibition. Tumors showing activating mutations in the EGFR gene are strikingly dependent on EGFR activity for their growth and survival [39]. Therefore, several agents specifically addressed to the EGFR have been developed, such as the monoclonal antibody cetuximab and three generations of tyrosine kinase inhibitors (e.g., erlotinib, afatinib, and osimertinib).

The G-quadruplex (G4) is a four-stranded structure formed by G-rich sequences, either DNA or RNA, which has at least two stacked G-tetrads [40,41]. A G-tetrad is a planar square arrangement of four guanines stabilized by Hoogsteen hydrogen bonds and monovalent cations [42]. During the last decade, G4s have emerged as possible druggable anticancer targets because they are located in key genome regions, like telomeres and oncogene promoters. In particular, small molecules that bind and stabilize the G4 in oncogene promoters may lead to downregulation of oncogene expression [43]. In this work, we focused our attention on the G4 structures within Kirsten ras (KRAS) and B-cell lymphoma2 (BCL2) genes. The KRAS gene is overexpressed in about $30 \%$ of all human cancers [44]. The Bcl-2 family of proteins is the main regulator of apoptotic process, acting either to promote or inhibit it [45]. Overexpression of BCL2 gene, which encodes the anti-apoptotic Bcl-2 protein, greatly contributes to the resistance of cancer cells to apoptosis, and it has also been reported to play a role in the resistance to conventional cancer treatments [46]. Although significant progress has been made in this research area, with some compounds reaching the advanced phases of clinical trials [47], a therapeutic approach based upon G4 ligands is challenging as many of them display low selectivity to the targeted G4 structure. Therefore, the search for novel chemical entities targeting $G$ quadruplexes is of huge interest.

\section{Results}

\subsection{Chemistry}

The 5-amino-3-methyl-1-phenyl-1H-pyrazole-4-carbonitrile $\mathbf{1}$ has served as a key starting material. It was prepared according to the previously reported method [24]. In order to synthesize the target pyrazolopyrimidinone bearing hydrazide-hydrazone derivatives, the hydrazide 3 has been prepared as depicted in Scheme 1. The first step 


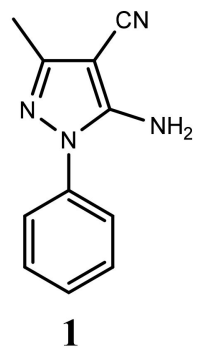

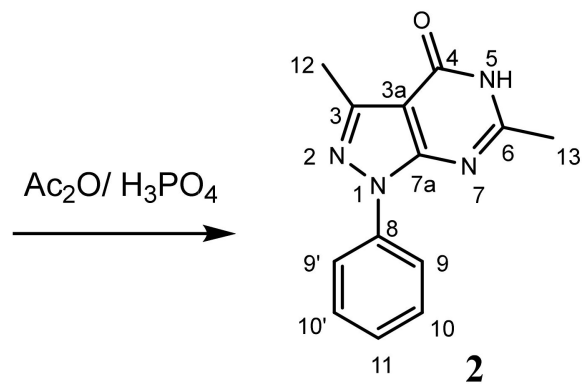

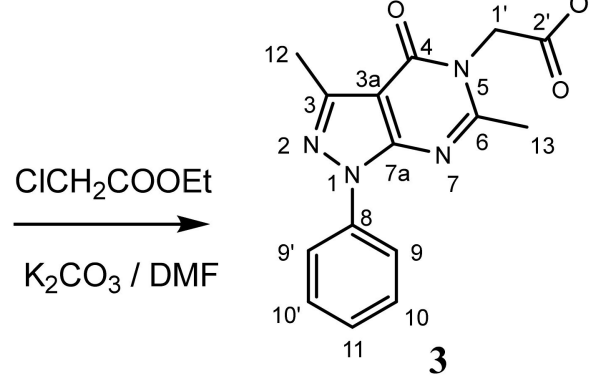

involves the synthesis of pyrazolopyrimidinone 2 by reaction of precursor 1 under reflux of acetic anhydride and in the presence of a determined volume of phosphoric acid. Compound 2 was treated with ethyl chloroacetate affording compound 3 in $75 \%$ yield. Then, ester 3 was submitted to nucleophilic substitution with hydrazine monohydrate obtaining pyrazolo-pyrimidinic hydrazide 4 in $55 \%$ yield. Structures of compounds 1, 2, 3, and 4 were established through their ${ }^{1} \mathrm{H}$ NMR and ${ }^{13} \mathrm{C}$ NMR spectra after purification and the results are shown in the experimental section. Subsequently, the key 4 was coupled with different arylaldehydes in ethanol and some drops of hydrochloric acid, thus obtaining hydrazide-hydrazones $\mathbf{5 a}-\mathbf{h}$ in $60-78 \%$ yields (Table 1). The synthetic strategy is depicted in Scheme 2. The structures of the target derivatives were characterized by ${ }^{1} \mathrm{H} \mathrm{NMR},{ }^{13} \mathrm{C}$ $\mathrm{NMR}$, and high resolution mass spectra (HRMS) spectroscopic techniques. Indeed, the ${ }^{1} \mathrm{HNMR}$ spectra of compounds 5 showed the disappearance of the signals at $4.34 \mathrm{ppm}$ relative to " $-\mathrm{NH}_{2}$ » of hydrazide and the appearance of new signals corresponding to the protons introduced by arylaldehyde. Analysis of ${ }^{13} \mathrm{C}$ NMR spectra of the same compounds demonstrated the desired structures through the appearance of aromatic and the iminic carbons $\mathrm{C}_{5^{\prime}}$. Furthermore, the electrospray ionization high resolution mass spectra (ESIHRMS) of all the examined compounds $\mathbf{5} \mathbf{a}-\mathbf{h}$ showed the correct protonated molecular ion peaks $[\mathrm{M}+\mathrm{H}]^{+}$, which is consistent with the molecular formula.

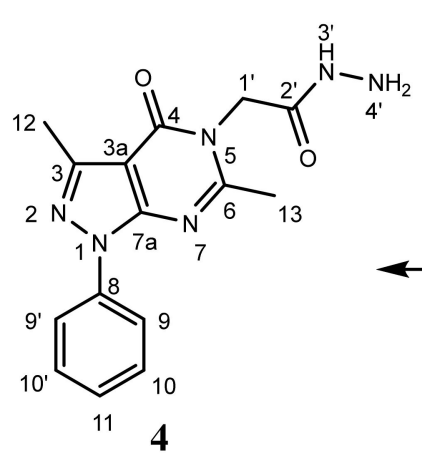

Scheme 1. Synthetic pathway to the precursors 2,3, and 4 .

Table 1. Synthesis of derivatives $5 \mathbf{a}-\mathbf{h}$.

\begin{tabular}{ccc}
\hline Compound & $\mathbf{R}$ & Yield (\%) \\
\hline $\mathbf{5 a}$ & $\left.4-\mathrm{N}^{-} \mathrm{CH}_{3}\right)_{2}$ & 60 \\
$\mathbf{5 b}$ & $4-\mathrm{OCH}_{3}$ & 75 \\
$\mathbf{5}$ & $4-\mathrm{NO}_{2}$ & 78 \\
$\mathbf{5 d}$ & $3,4-d i \mathrm{OCH}_{3}$ & 70 \\
$\mathbf{5 e}$ & $3-\mathrm{OC}_{2} \mathrm{H}_{5}, 4-\mathrm{OH}$ & 62 \\
$\mathbf{5 f}$ & $4-\mathrm{F}$ & 68 \\
$\mathbf{5 g}$ & $2-\mathrm{OH}, 5-\mathrm{Br}$ & 64 \\
$\mathbf{5 h}$ & $4-\mathrm{Br}$ & 72 \\
\hline
\end{tabular}


<smiles>Cc1nn(-c2ccccc2)c2nc(C)n(CC(=O)NN)c(=O)c12</smiles>

4

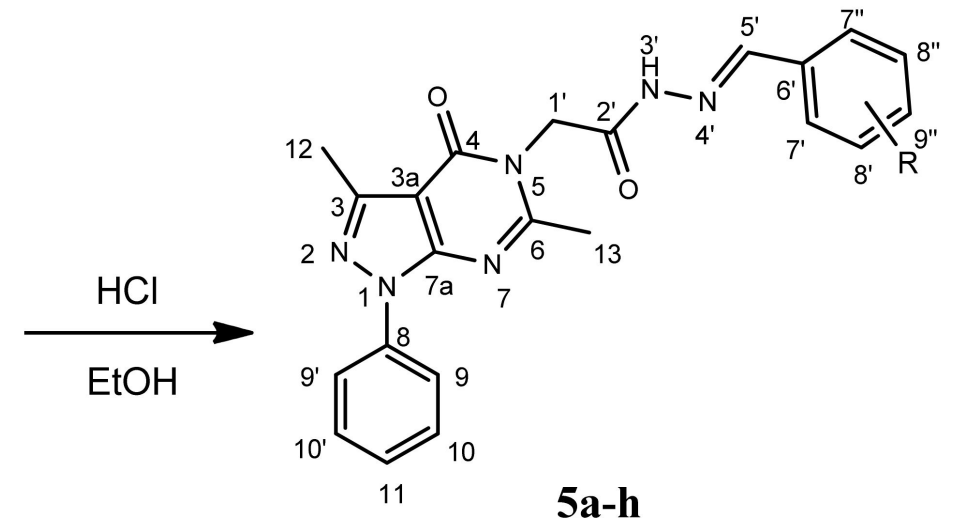

Scheme 2. Synthetic pathway of pyrazolopyrimidinones $\mathbf{5 a}-\mathbf{h}$.

\subsection{In Vitro Evaluation of Antiproliferative Activity in MCF-7 Breast Cancer Cells}

Twelve synthetic compounds $(\mathbf{1}, \mathbf{2}, \mathbf{3}, \mathbf{4}, \mathbf{5 a}, \mathbf{5 b}, \mathbf{5 c}, \mathbf{5 d}, \mathbf{5 e}, \mathbf{5 f}, \mathbf{5 g}$, and $\mathbf{5 h})$ were initially assessed for their antitumor activity against breast adenocarcinoma MCF-7 cell line, at a single dose exposure $(50 \mu \mathrm{M})$. Cancer cell viability was monitored for $48 \mathrm{~h}$ after drug administration, by using the real-time xCELLigence cell analyzer, which allows to evaluate proliferation of cells growing on microsensor electrodes. Drug-induced antiproliferative effects elicit electronic impedance reduction, which is translated into a unit-less parameter, namely cell index (CI), thereby reflecting cellular adhesion, growth, and morphology states.

Real time monitoring of cancer cell proliferation unveiled that $5 \mathrm{a}, 5 \mathrm{e}, 5 \mathrm{~g}$, and $5 \mathrm{~h}$ were the most bioactive molecules of the series and were shown to exert significant antiproliferative activity already within the first $24 \mathrm{~h}$ of treatment (Figure 2). Notably, MCF-7 cells experienced a substantial drop in the CI value after incubation with $50 \mu \mathrm{M}$ of compound $5 \mathbf{h}$, which resulted to be approximately 2 times more potent than cisplatin, one of the most widely used and effective chemotherapeutic drugs for treatment of solid tumors, such as ovarian, testicular, and bladder carcinoma [48]. Moreover, cisplatin is also used as adjuvant/neoadjuvant agent in breast cancer patients and as a single chemo drug or in combination with other medications, for the treatment of advanced and triple negative breast cancer.

Growth inhibition was rather severe but less pronounced in MCF-7 cells exposed to $5 \mathbf{a}, 5 \mathbf{e}$, and $5 \mathbf{g}(50 \mu \mathrm{M})$, with the latter exhibiting similar extent of cytotoxicity as cisplatin towards breast cancer cells (Figure 2A).

In single treatment, MCF-7 cells were incubated with different concentrations (6.25, $12.5,25,50,100 \mu \mathrm{M})$ of $\mathbf{5 a}, \mathbf{5 e}, \mathbf{5} \mathbf{g}$, and $\mathbf{5 h}$ to assess the half-maximal inhibitory concentration $\left(\mathrm{IC}_{50}\right)$ of individual synthetic derivatives. The growth rate of tumor cells, monitored by $x$ CELLigence real-time cell analysis, was significantly inhibited by each of the aforementioned molecules, in a dose-dependent manner. The $\mathrm{IC}_{50}$ values of $\mathbf{5 a}, \mathbf{5 e}, \mathbf{5} \mathbf{g}$, and $5 \mathrm{~h}$, determined after $24 \mathrm{~h}$ of incubation, were $55.3,60.0,45.4$, and $34.6 \mu \mathrm{M}$, respectively (Figure 2B).

To test whether apoptosis induction contributed to growth inhibitory potency of $\mathbf{5 a}$, $5 \mathbf{e}, 5 \mathrm{~g}$, and $5 \mathbf{h}$, we evaluated the apoptotic rate of MCF-7 cells by an Annexin V-fluorescein isothiocyanate (FITC)/Propidium iodide (PI) staining assay (Figure 3). MCF-7 cells were treated with $\mathrm{IC}_{50}$ concentrations of each compound for $24 \mathrm{~h}$. All compounds were shown to induce significant apoptotic cell death in breast cancer cells as compared to controls exposed to $0.5 \%$ dimethyl sulfoxide (DMSO) vehicle, with $\mathbf{5 e}$ and $\mathbf{5 g}$ causing higher rates of apoptosis (69.6\% and 59.3\%, respectively). Interestingly, although apoptosis was the major cell death mechanism, $5 \mathrm{~h}$ turned out to be the only compound to trigger mild but significant necrotic cell injury.

Aiming to assess whether cell cycle arrest could underly the antiproliferative effects of $\mathbf{5 a}, \mathbf{5 e}, \mathbf{5 g}$, and $\mathbf{5 h}$ in MCF-7 cancer cells, flow cytometry cell cycle analysis was performed 
using propidium iodide DNA staining in live cells (Figure 4). Incubating MCF-7 with $\mathrm{IC}_{50}$ concentrations of each compound for $24 \mathrm{~h}$ led to cell cycle arrest in the $\mathrm{G}_{1} / \mathrm{G}_{0}$ phase, thereby decreasing the proportion of cells in the $S$ and G2/M phases.

A)

MCF-7 24h treatment

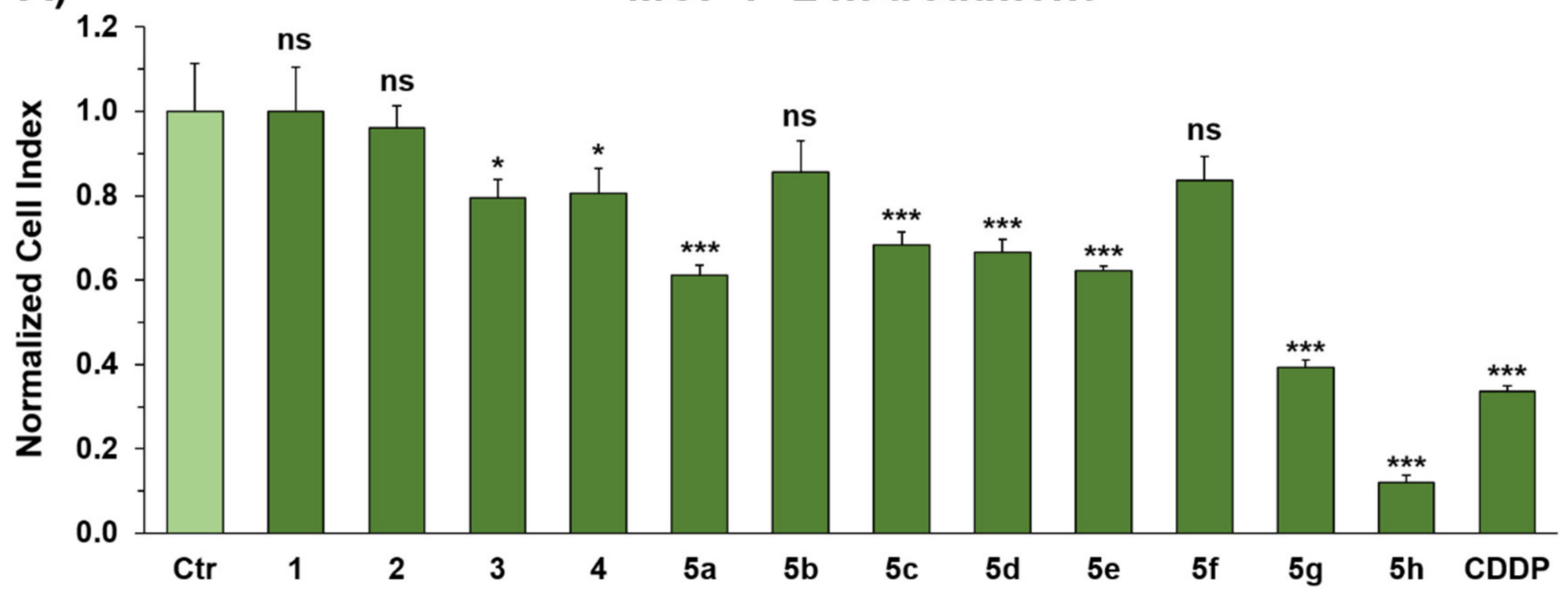

B)

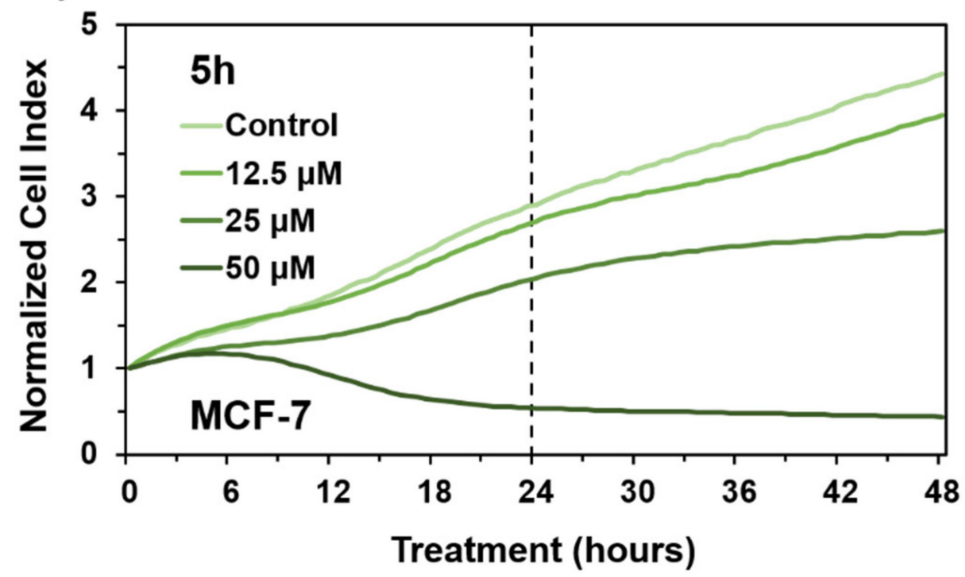

$\mathrm{IC}_{50}$ MCF-7

\begin{tabular}{cc}
\hline Compound & $\mathrm{IC}_{\mathbf{5 0}}(\mu \mathrm{M}) \pm \mathrm{SE}$ \\
\hline $\mathbf{5 a}$ & $55.34 \pm 7.711$ \\
$\mathbf{5 e}$ & $60.02 \pm 2.716$ \\
$\mathbf{5 g}$ & $45.41 \pm 5.376$ \\
$\mathbf{5 h}$ & $34.55 \pm 2.381$ \\
\hline
\end{tabular}

Figure 2. Real time monitoring of breast cancer MCF-7 cell viability after 24 h exposure to synthetic compounds 1, 2, 3, 4, $\mathbf{5 a}, \mathbf{5 b}, \mathbf{5 c}, \mathbf{5 d}, \mathbf{5 e}, \mathbf{5 f}, \mathbf{5 g}$, and $\mathbf{5 h}$ and $0.5 \%$ dimethyl sulfoxide (DMSO) vehicle (control), using the xCELLigence System Real-Time Cell Analyzer. (A) Normalized Cell Index (NCI) variations of MCF-7 cancer cells after $24 \mathrm{~h}$ incubation with $0.5 \%$ DMSO vehicle (Ctr, control) and $50 \mu \mathrm{M}$ of cisplatin (CDDP), $\mathbf{1}, \mathbf{2}, \mathbf{3}, \mathbf{4}, \mathbf{5 a}, \mathbf{5 b}, \mathbf{5} \mathbf{c}, \mathbf{5 d}, \mathbf{5 e}, \mathbf{5 f}, \mathbf{5 g}$, and $\mathbf{5 h}$. NCI values are relative to controls treated with $0.5 \%$ DMSO vehicle. Data are presented as mean $\pm \mathrm{SD} ; n=3$. Statistical significances are referred to the DMSO control. Differences between groups were determined by analysis of variance (ANOVA) and Dunnett's test was used for multiple comparisons with the control. ${ }^{*} p<0.05 ;{ }^{* * *} p<0.0001$ (B) Left panel: Representative NCI traces of MCF-7 cells exposed to increasing concentrations $(12.5,25,50 \mu \mathrm{M})$ of $5 \mathbf{h}$ and $0.5 \%$ DMSO vehicle (control) for 48 h. Right panel: Half-maximal inhibitory concentration ( $\left.\mathrm{IC}_{50}\right)$ values ( \pm standard error, SE) of $\mathbf{5 a}, \mathbf{5 e}, \mathbf{5 g}$, and $\mathbf{5 h}$ against MCF-7 cells after $24 \mathrm{~h}$ drug exposure. The $\mathrm{IC}_{50}$ value represents the concentration of each compound that reduces the NCI by $50 \%$. Data are means of three independent experiments. 


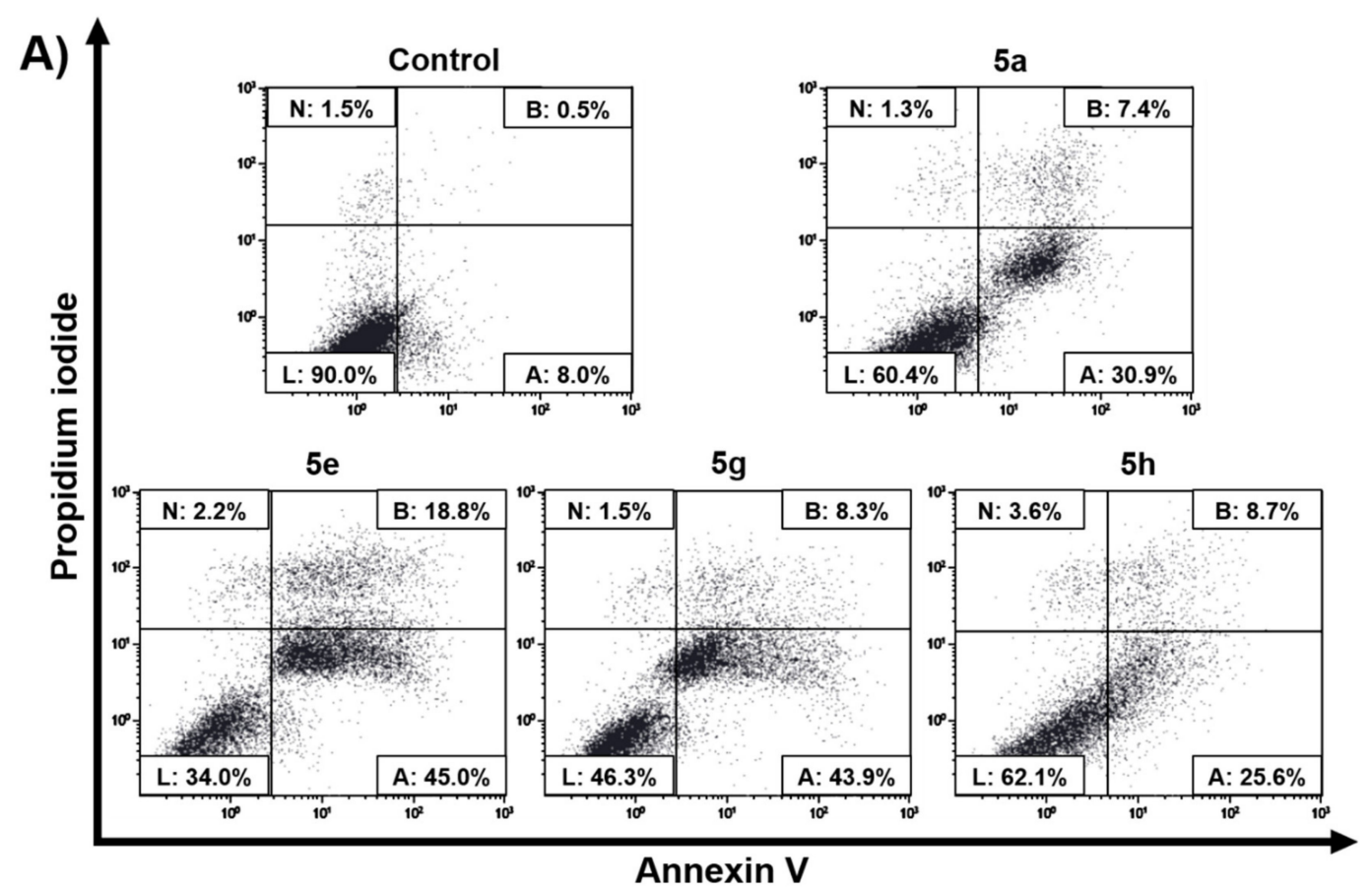

B)

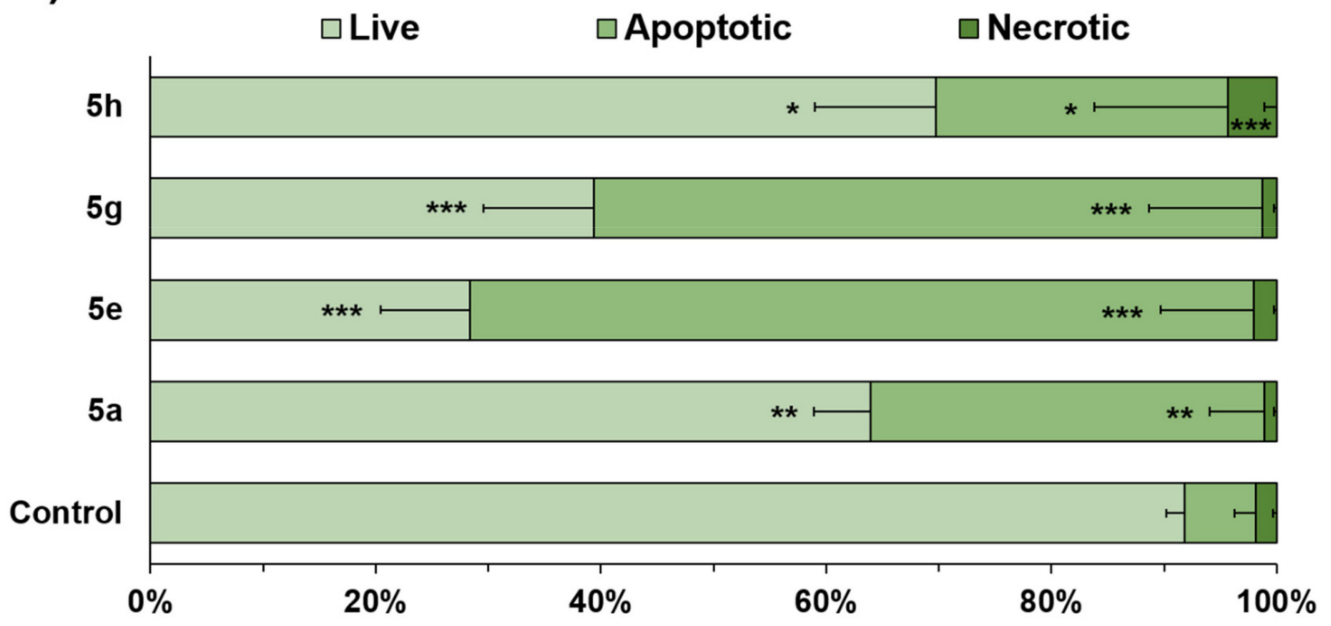

Figure 3. Flow cytometric detection of apoptosis and necrosis with Annexin-V-fluorescein isothiocyanate (FITC) and propidium iodide staining in MCF-7 cells after $24 \mathrm{~h}$ exposure to $0.5 \%$ DMSO vehicle (control) and $\mathrm{IC}_{50}$ concentrations of the selected derivatives $\mathbf{5 a}, \mathbf{5 e}, \mathbf{5 g}$, and $\mathbf{5 h}$. (A) Dot plots show a single representative experiment. Abbreviations: L, live cells; A, early apoptotic cells; B, late apoptotic cells; N, necrotic cells. (B) Relative amount of live, necrotic, and apoptotic cells after $24 \mathrm{~h}$ incubation with $\mathrm{IC}_{50}$ concentrations of $\mathbf{5 a}, \mathbf{5 e}, \mathbf{5} \mathbf{g}$, and $\mathbf{5 h}$ and $0.5 \%$ DMSO vehicle (control). Percent of apoptotic cells was obtained from the sum of early and late apoptosis. Data are presented as mean $\pm \mathrm{SD} ; n=3$. Statistical significances are referred to the DMSO control. Differences between groups were determined by analysis of variance (ANOVA), and Dunnett's test was used for multiple comparisons with the control. ${ }^{*} p<0.05 ;{ }^{* *} p<0.01 ;{ }^{* * *} p<0.0001$.

Next, we evaluated detailed response curves for compounds $\mathbf{5 a}, \mathbf{5 e}, \mathbf{5 g}$, and $\mathbf{5 h}$ in normal human dermal fibroblasts (NHDF) to probe putative differential effects on tumor versus normal cells. NHDF were exposed to increasing doses of $\mathbf{5 a}, \mathbf{5 e}, \mathbf{5} \mathbf{g}$, and $\mathbf{5 h} \mathbf{h}(6.25$, $12.5,25,50,100 \mu \mathrm{M}$ ) and then, cell viability was monitored for $48 \mathrm{~h}$, using the xCELLigence system (Figure S1). The cytotoxic effects of the four synthesized molecules in breast cancer cells were not selective as they also inhibited cell survival in the normal cell model, with 
almost similar $\mathrm{IC}_{50}$ values. However, $\mathbf{5 a}, \mathbf{5 e}, \mathbf{5 g}$, and even the most potent compound, $\mathbf{5 h}$, were shown to exert less toxicity than cisplatin against NHDF cells (Figure S1).
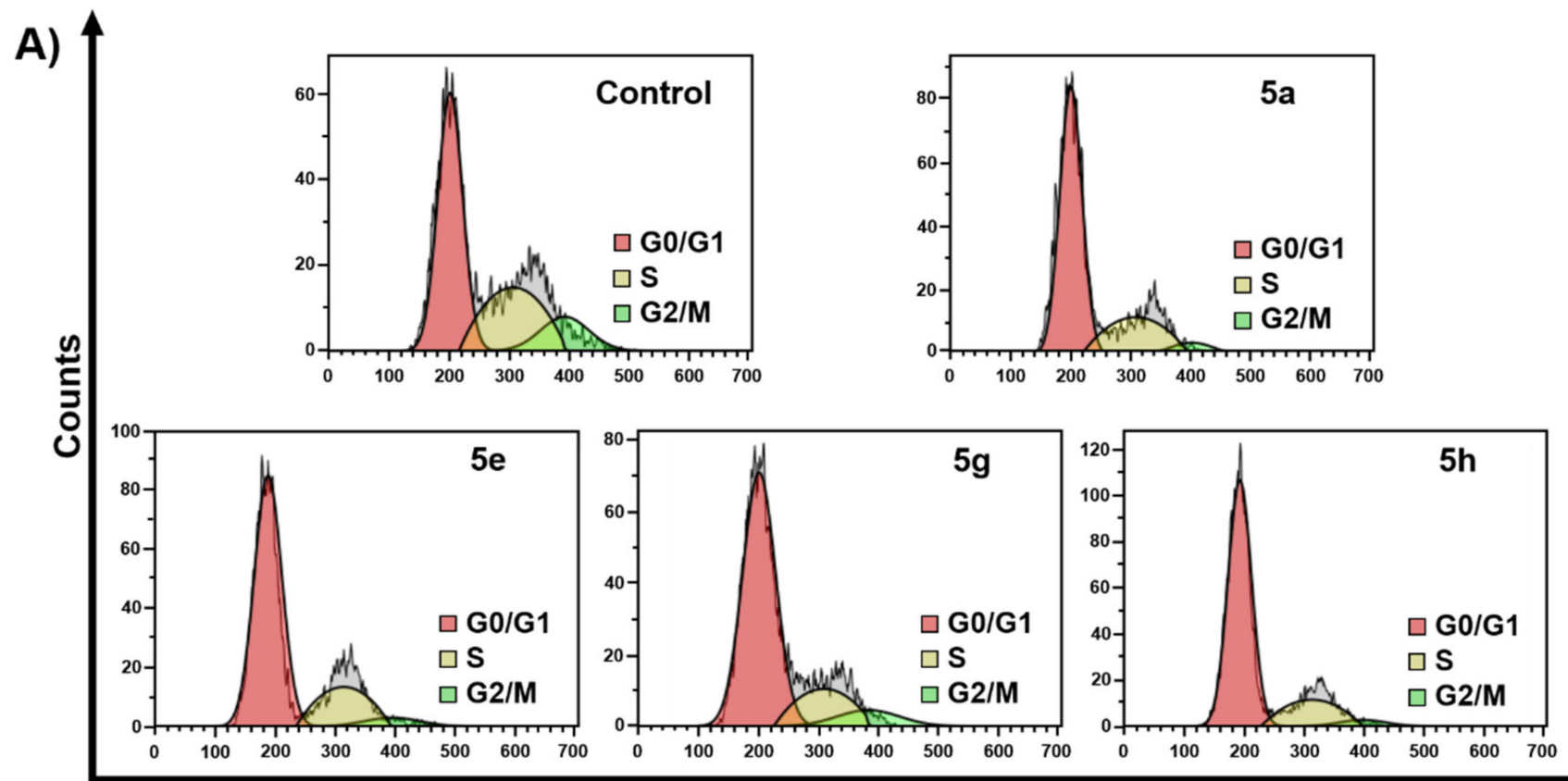

Propidium iodide

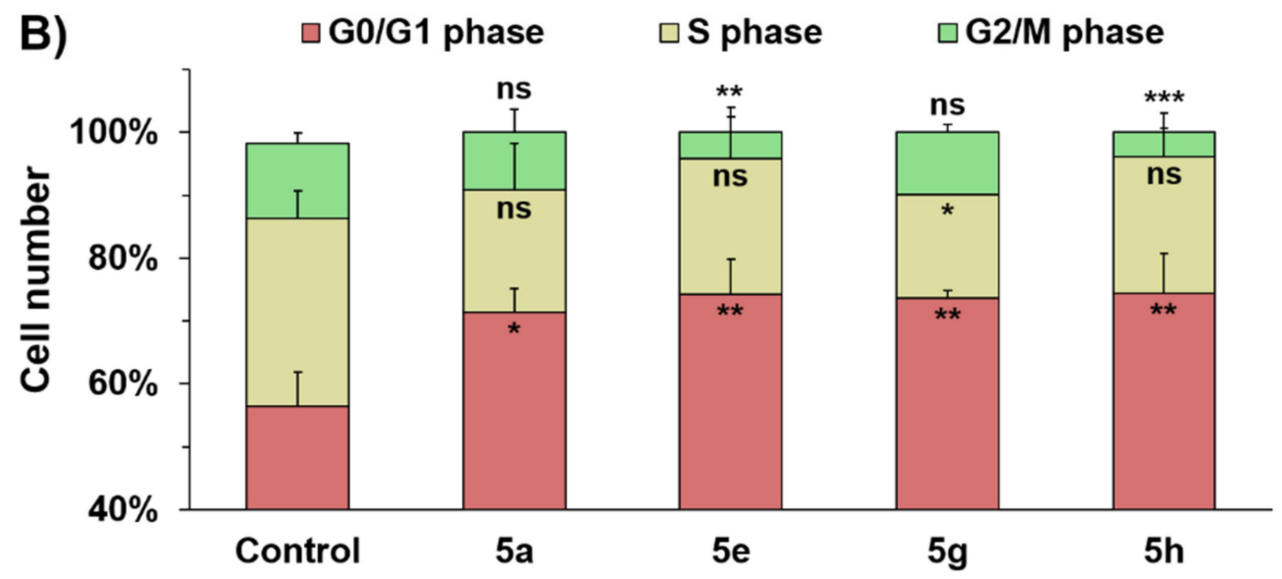

Figure 4. Flow cytometry cell cycle analysis of MCF-7 cells exposed for $24 \mathrm{~h}$ to $\mathrm{IC}_{50}$ concentrations of $\mathbf{5 a}, \mathbf{5 e}, \mathbf{5 g}$, and $\mathbf{5 h}$ and $0.5 \%$ DMSO vehicle (control). (A) Cell cycle histogram plots show a single representative experiment. (B) Cell cycle distribution of MCF-7 cells treated with $\mathrm{IC}_{50}$ concentrations of $\mathbf{5 a}, \mathbf{5 e}, \mathbf{5 g}$, and $\mathbf{5 h}$ and $0.5 \%$ DMSO vehicle for $24 \mathrm{~h}$. Data are presented as mean $\pm \mathrm{SD} ; n=3$. Statistical significances are referred to the DMSO control. Differences between groups were determined by analysis of variance (ANOVA), and Dunnett's test was used for multiple comparisons with the control. ${ }^{*} p<0.05 ;{ }^{* *} p<0.01 ;{ }^{* * *} p<0.0001$.

\subsection{Identification of Potential Anticancer Drug Targets of $5 \boldsymbol{a}, \mathbf{5 e}, \mathbf{5 g}$, and $\mathbf{5 h}$}

2.3.1. In Silico Molecular Docking of $\mathbf{5 a}, \mathbf{5 e}, \mathbf{5 g}$, and $\mathbf{5 h}$ as Epidermal Growth Factor Receptor Tyrosine Kinase Inhibitors

EGFR is the first member of the Her receptor family which plays a conspicuous role in cellular signaling activities, including cell proliferation, growth, adhesion, differentiation, metabolism, motility, and death [49-51]. Therefore, EGFR has been regarded as a valuable anticancer target in medicinal chemistry. As several EGFR inhibitors shared structural moieties with our synthetic compounds [52-54], we explored putative binding 
interactions of $\mathbf{5 a}, \mathbf{5 e}, \mathbf{5 g}$, and $\mathbf{5 h}$ with this receptor. In addition, EGFR inhibition has been already demonstrated to enhance cell death pathways (e.g., apoptosis, autophagy) in MCF7 cells [55-57].

With this regard, a literature survey revealed that molecular docking into the ATP binding site of EGFR (protein data bank ID: 1M17) was a robust strategy for identification of effective EGFR inhibitors endowed with cytotoxic properties [58-60]. In the current study, docking simulations using the crystal structure of EGFR, co-crystallized with its inhibitor erlotinib, has been performed to elucidate the interactions of the active cytotoxic agents $\mathbf{5 a}, \mathbf{5 e}, \mathbf{5 g}$, and $\mathbf{5 h}$ at the 'Erlotinib' binding domain of tyrosine kinase enzyme (protein data bank ID: 1M17), by using Autodock 4.2 (Table 2). The EGFR protein was previously pre-treated by removing all bound water molecules and adding the polar hydrogen atoms and Gasteiger charges to the system during the preparation of the receptor input file. Then, AutoDock Tools were used for the preparation of the corresponding ligand and protein files (PDBQT). Next, pre-calculation of the grid maps was performed using Auto Grid for saving time during the docking procedure.

Table 2. Binding energies of promising cytotoxic agents.

\begin{tabular}{ccccccc}
\hline Compound & \multicolumn{5}{c}{ Binding Energy (kcal/mol) } \\
\hline Erlotinib & -7.1 & -6.9 & 6.8 & 6.8 & 6.8 & -6.6 \\
$\mathbf{3}$ & -8.0 & -7.6 & -7.5 & -7.4 & -7.3 & -7.1 \\
$\mathbf{5 a}$ & -8.9 & -8.5 & -8.4 & -8.4 & -8.0 & -7.9 \\
$\mathbf{5 e}$ & -8.9 & -8.7 & -8.6 & -8.4 & -8.2 & -8.1 \\
$\mathbf{5 g}$ & -9.1 & -8.8 & -8.2 & -8.1 & -8.1 & -8.1 \\
$\mathbf{5 h}$ & -8.9 & -8.7 & -8.7 & -8.5 & -8.3 & -8.3 \\
\hline
\end{tabular}

The majority of cytotoxic agents reported so far, resembles the binding interaction of Erlotinib within the active site.

Indeed, regarding to the hydrazide-hydrazone conjugates $5 \mathrm{a}, \mathbf{5 e}, \mathbf{5 g}$, and $5 \mathrm{~h}$, it can be noticed that they are involved in conventional Hydrogen bond with MET-A-769 through $\mathrm{NH}$ group. Pi-Sulfur bond was observed between MET-A-742 (highlighted in yellow color in Figure 5) and the phenyl moiety. Furthermore, Pi-Anion bond was formed by the pyrazole ring and ASP-A-831 (highlighted in golden color in Figure 5), in addition to PiSigma interactions formed by the pyrazolopyrimidinone fragment and amino acids: VALA-702 and LEU-A-820. Moreover, all derivatives showed many hydrophobic interactions (Alkyl and Pi-Alkyl with amino acids sequence: LEU-A-694, VAL-A-702, LYS-A-704, ALAA719, LYS-A-721, MET-A-769, and LEU-A-820), except for 5g (having the lowest binding energy values), which displayed a second hydrogen bond through its hydroxy group with PRO-A-770. This finding demonstrates that this compound is more active than its analogs. On another hand, the conjugate $5 \mathrm{~h}$ is nicely bound to the ATP binding site of EGFR through an Alkyl interaction with PHE-A-699, in addition to a Carbon-Hydrogen bond formed by the $\mathrm{CH}$ group of hydrazide-hydrazone pharmacophore with MET-A-769, as well as the other interactions mentioned above (Figure 5). From this binding model, it could be concluded that these last interactions are responsible for the effective EGFR inhibitory of these compounds, especially $5 \mathrm{~g}$ and $5 \mathrm{~h}$.

\subsubsection{Physicochemical Evaluation of $\mathbf{5 a}, \mathbf{5 e}, \mathbf{5} \mathbf{g}$, and $\mathbf{5 h}$ as G-Quadruplex DNA Stabilizers}

To investigate the in vitro binding properties of synthesized molecules versus G4 structures Circular Dichroism (CD) spectroscopy and CD melting experiments were carried out. Two G4 forming sequences from KRAS (KRAS 22RT) and BCL2 (BCL2-G4) oncogene promoter regions, and a G4 from human telomere (Tel23), were used in these experiments. A 20-mer hairpin-duplex DNA consisting of two self-complementary 8-mer sequences connected by a TTTT loop (hairpin duplex) was also used to estimate the G4 over duplex selectivity of the ligands. Initially, the conformation of each DNA sample was verified by CD spectroscopy. The CD spectrum of KRAS 22RT, showed a positive band at $264 \mathrm{~nm}$ 
and a negative band at $240 \mathrm{~nm}$, in agreement with the presence of parallel G4 topology (Figure 6). Otherwise, BCL2-G4 and Tel 23 showed two positive bands at around 265 and $290 \mathrm{~nm}$ and a weak negative band at $240 \mathrm{~nm}$, in agreement with a hybrid structure as major conformation. The structure of hairpin duplex was also verified by $\mathrm{CD}$, showing the typical spectrum of a duplex DNA (Figure S3). To verify if the compounds $\mathbf{5 a}, \mathbf{5 e}, \mathbf{5 g}$, and $5 \mathrm{~h}$ alter the native folding topologies of the investigated sequence, $\mathrm{CD}$ experiments were performed by adding an excess of each ligand to the pre-folded G4 structure. Notably, no CD spectra changes were observed upon addition of each ligand (Figure S3). The stabilizing effect of each compound was evaluated by $\mathrm{CD}$ melting experiments by measuring the ligand-induced change in the melting temperature $\left(\Delta T_{\mathrm{m}}\right)$ of both $\mathrm{G} 4$ and duplex structures. CD melting results show that only $\mathbf{5 a}$ has the capability to stabilize KRAS 22RT with a $\Delta T_{\mathrm{m}}$ of $+7{ }^{\circ} \mathrm{C}$ (Table 3) and shows selectivity for G4 structures over duplex DNA (Figure 6).
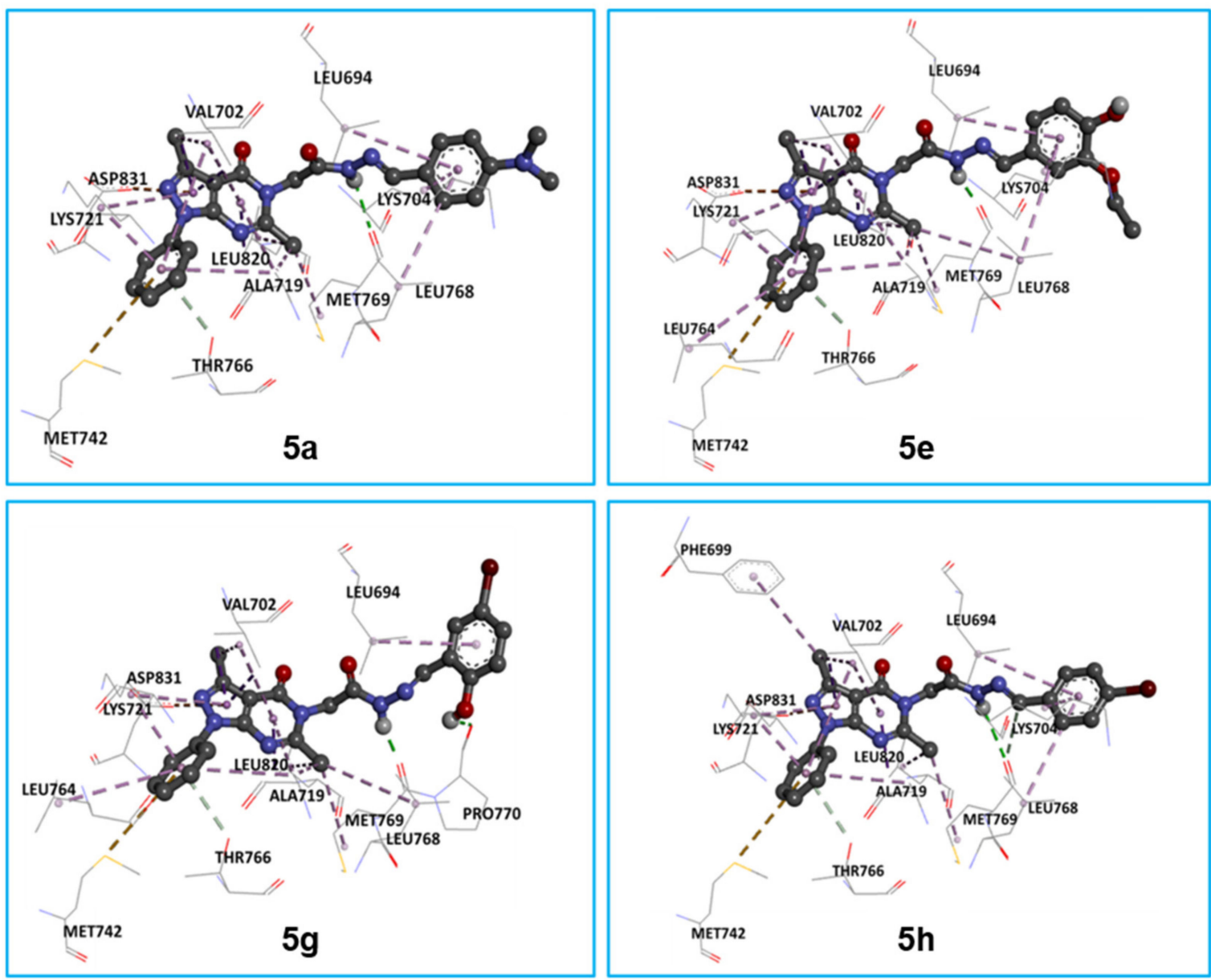

Figure 5. Binding modes of conjugates $5 \mathrm{a}, \mathbf{5 e}, \mathbf{5 g}$, and $\mathbf{5 h}$ in the erlotinib binding site of the epidermal growth factor receptor (EGFR) (PDB: 1M17).

Table 3. $\Delta T_{\mathrm{m}}$ of analyzed sequences in the presence of $\mathbf{5 a}, \mathbf{5 e}, \mathbf{5 g}$, and $5 \mathbf{h} .{ }^{1} \Delta \mathrm{T}_{\mathrm{m}}$ values are the differences in the melting temperatures of DNA in the presence and absence of ligands. The error on $\Delta T_{\mathrm{m}}$ is $\pm 0.5^{\circ} \mathrm{C}$.

\begin{tabular}{ccccc}
\hline Ligand & $\begin{array}{c}\text { KRAS 22RT } \\
\Delta T_{\mathrm{m}}\left({ }^{\circ} \mathrm{C}\right)^{\mathbf{1}}\end{array}$ & $\begin{array}{c}\text { BCL2-G4 } \\
\Delta T_{\mathrm{m}}\left({ }^{\circ} \mathrm{C}\right)^{\mathbf{1}}\end{array}$ & $\begin{array}{c}\text { Tel 23 } \\
\Delta T_{\mathrm{m}}\left({ }^{\circ} \mathrm{C}\right)^{\mathbf{1}}\end{array}$ & $\begin{array}{c}\text { Hairpin Duplex } \\
\Delta T_{\mathrm{m}}\left({ }^{\circ} \mathrm{C}\right)^{\mathbf{1}}\end{array}$ \\
\hline $\mathbf{5 a}$ & +7.0 & -3.0 & -3.2 & +1.0 \\
$\mathbf{5 e}$ & 0 & 0 & 0 & +5.4 \\
$\mathbf{5 g}$ & 0 & 0 & -2.0 & 0 \\
$\mathbf{5 h}$ & 0 & +1.0 & +1.0 & +3.3 \\
\hline
\end{tabular}




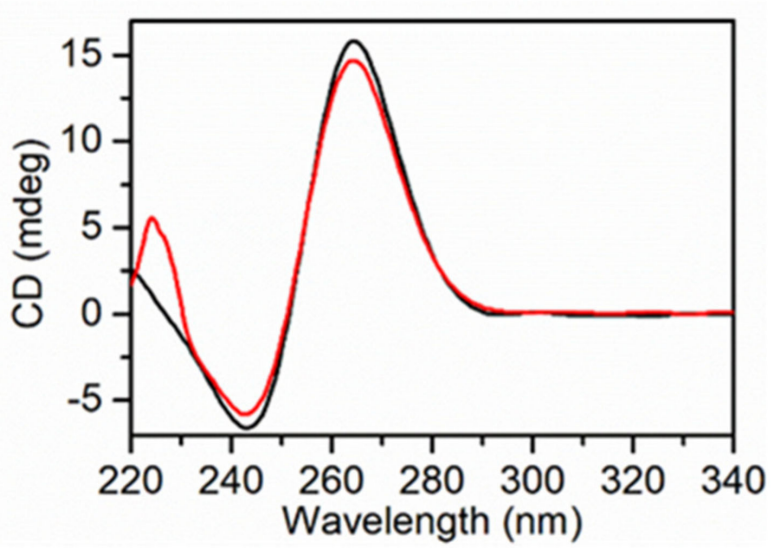

(a)

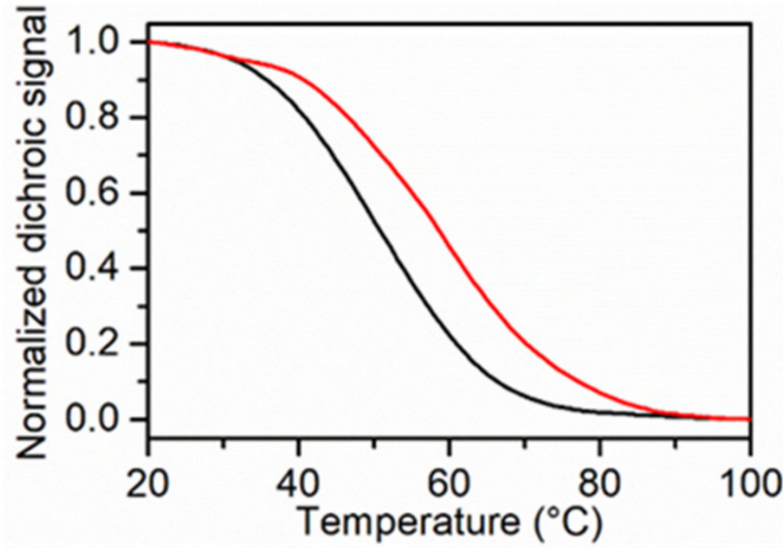

(b)

Figure 6. (a) Circular Dichroism (CD) spectra of KRAS 22RT in the absence (black line) and in the presence (red line) of $5 \mathbf{a}$. (b) CD melting curves of KRAS 22RT in the absence (black line) and in the presence (red line) of $5 \mathbf{a}$.

\section{Discussion}

In the current work, we have successfully designed and synthesized a new series of pyrazolo-pyrimidinones bearing hydrazide-hydrazone derivatives $\mathbf{5 a}-\mathbf{h}$ via reaction of hydrazide 4, previously prepared starting from the 5-amino-3-methyl-1-phenyl-1Hpyrazole-4-carbonitrile 1 with substituted arylaldehydes. Among these compounds, 5a, $5 \mathrm{e}, 5 \mathrm{~g}$, and $5 \mathrm{~h}$ were shown to exert significant cell-growth inhibition in MCF-7 breast cancer cells, thereby inducing apoptosis and G0/G1 phase cell cycle arrest. Notably, in cell viability assays, $5 \mathbf{h}$ was the most bioactive derivative and showed a) more effective antiproliferative properties against MCF-7 cells and b) less cytotoxicity towards normal dermal fibroblasts than cisplatin, which was used as reference drug in our screening. Compounds $5 \mathrm{a}, \mathbf{5 e}, \mathbf{5 g}$, and $\mathbf{5 h}$ did not display selectivity towards cancerous cells as they also inhibited cell survival in the normal cell model, with almost similar IC $_{50}$ values (Figure 2 and Figure S1). However, NHDF cells appeared to be more vulnerable to cisplatin rather than synthetic compounds, which could exhibit higher tolerability and cause less damage to healthy tissues.

The proposed pyrazolo-pyrimidinone scaffold tethered with hydrazide-hydrazone derivatives represents an essential feature to keep cytotoxic activity against MCF-7 cell line. Indeed, compounds 1-4, which lack the aryl-hydrazone moiety, resulted to be among the less bioactive compounds tested in this study. In regard to the chemical nature of substituents on the aryl-hydrazone moiety, two bioactivity trends seemed to emerge from antiproliferative assays: (a) insertion of a bulky halogen atom (such as bromine) in $5 \mathrm{~h}$ led to a significant enhancement of cytotoxic activity as compared to the fluorine derivative $\mathbf{5 f}$; (b) increasing hydrophobic steric hindrance of functional groups, such as $-\mathrm{N}\left(\mathrm{CH}_{3}\right)_{2}$ in $\mathbf{5 a}$, improves antiproliferative effects with respect to the methoxy derivative $\mathbf{5 b}$.

Interestingly, the greater cytotoxicity exerted by $\mathbf{5 a}$ and $\mathbf{5 h}$ correlates with their ability to form stronger and more stable interactions with the erlotinib binding site of EGFR, as compared to $\mathbf{5 b}$ and $\mathbf{5 f}$ in molecular docking simulations. Particularly, while $\mathbf{5 a}$ and $\mathbf{5 h}$ reorient the $\mathrm{NH}$ group of the hydrazone fragment to form the hydrogen bond with MET-A$\mathbf{7 6 9}$, this interaction is missing for their respective analogues $\mathbf{5 b}$ and $\mathbf{5 f}$ (Figure 7). This is explained by the crucial role of large groups in $\mathbf{5 a}$ and $5 \mathbf{h}\left(\mathrm{N}\left(\mathrm{CH}_{3}\right)_{2}\right.$ and $\mathrm{Br}$, respectively) for the stability of the enzyme-ligand complex and, therefore, for the inhibition of EGFR.

Molecular docking simulations using the crystal structure of EGFR, co-crystallized with its inhibitor erlotinib, provided evidence for high binding affinity of $\mathbf{5 a}, \mathbf{5 e}, \mathbf{5 g}$, and $\mathbf{5 h}$ towards EGFR. These results suggest that these molecules, at least partially, may exert their cytotoxic effects through EGFR inhibition, which correlates with the observed apoptosis induction and $\mathrm{G}_{0} / \mathrm{G}_{1}$ cell cycle arrest in cancer cells, after exposure to compounds $\mathbf{5 a}$, 
$\mathbf{5 e}, \mathbf{5 g}$, and $\mathbf{5 h}[61,62]$. The cytotoxic power of these four compounds is explained by the high number of various interactions formed: hydrophobic (Pi-Sigma, Pi-Alkyl, Alkyl), electrostatic (Pi-Anion), Pi-Sulfur, and especially hydrogen bond (Figure 5).
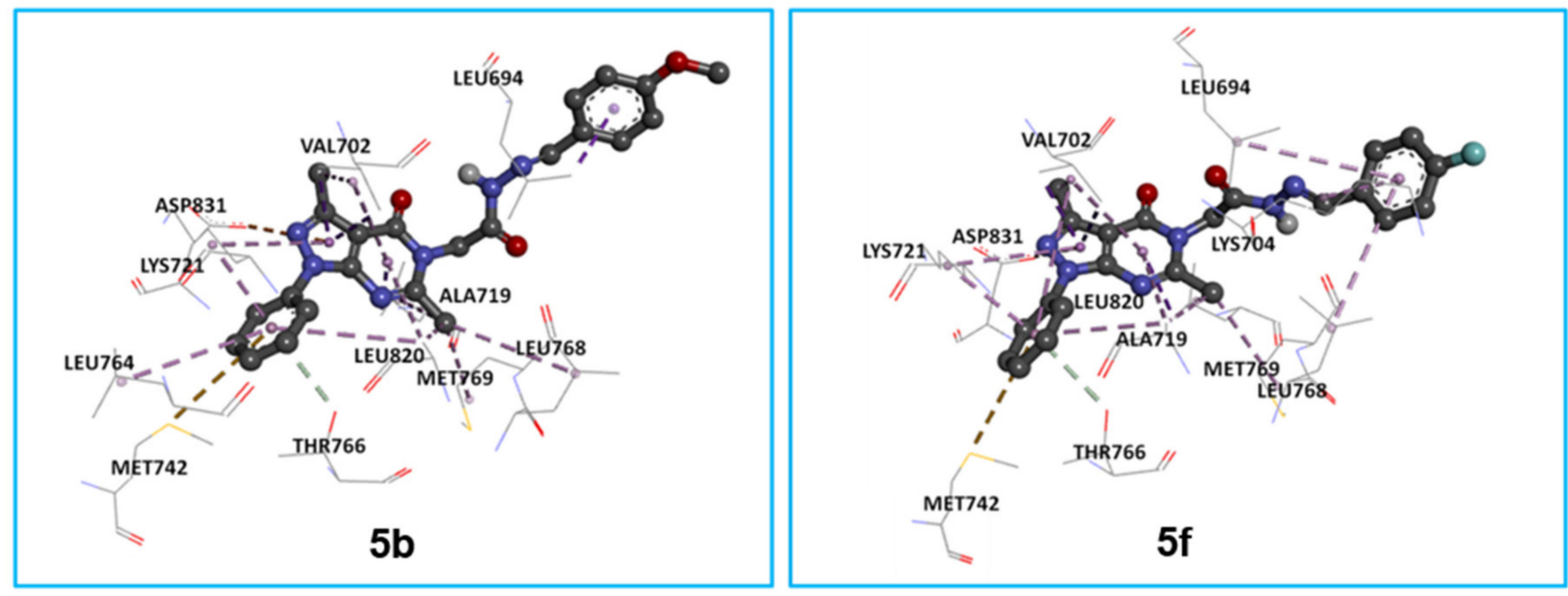

Figure 7. Binding modes of conjugates $\mathbf{5 b}$ and $\mathbf{5} \mathbf{f}$ in the erlotinib binding site of the EGFR (PDB: 1M17).

Moreover, physicochemical evaluation of $\mathbf{5 a}, \mathbf{5 e}, \mathbf{5} \mathbf{g}$, and $\mathbf{5 h}$ as G-Quadruplex DNA stabilizers, showed that only $\mathbf{5 a}$ enhanced thermal stability of KRAS 22RT, unveiling selectivity for G4 structures over duplex DNA. Besides the large aromatic flat surface, which is shared in all compounds, $\mathbf{5 a}$ is the only derivative to display a further structural requirement for efficient G4 ligands [63], that is the dimethylamino group at the para-position of the arylhydrazone motif. This group may be positively charged at the physiological $\mathrm{pH}$ and allow 5a to establish key electrostatic interactions for binding G4-DNA structures. In addition, $\mathrm{CD}$ experiments unveiled $\mathbf{5 e}$ and $\mathbf{5 h}$ to bind hairpin duplex DNA, thereby suggesting these molecules could form DNA adducts, contributing to the cytotoxic mechanism enhanced by these molecules.

Overall, our findings clearly indicate that the pyrazolo-pyrimidinone scaffold tethered with hydrazide-hydrazone derivatives represents a promising cytotoxic pharmacophore for anticancer drug development. Therefore, our efforts will be addressed toward improvement of biological properties of this chemical backbone, aiming to design either (a) selective EGFR inhibitors, using $\mathbf{5 g}$ and $\mathbf{5 h}$ as pivotal molecules or (b) more efficient G4 ligands, using $5 \mathbf{a}$ as lead compound.

\section{Materials and Methods}

\subsection{General Information}

The control of all reactions was monitored by TLC using aluminium sheets of Merck silica gel 60 F254, $0.2 \mathrm{~mm}$. Melting points were determined on an Electrothermal 9002 melting point apparatus and are uncorrected. NMR spectra were recorded on a Bruker Avance Neo spectrometer (Bruker BioSpin Corporation, Billerica, MA, USA) at $400 \mathrm{MHz}$ $\left({ }^{1} \mathrm{H}\right)$ and $100 \mathrm{MHz}\left({ }^{13} \mathrm{C}\right)$ using dimethylsulfoxide- $d_{6}$ as solvent. All chemical shifts were reported as $\delta$ values $(\mathrm{ppm})$ relative to residual solvent signal $\left(\delta_{\mathrm{H}} 2.50, \delta_{\mathrm{C}} 39.5\right)$. High Resolution Mass Spectra (HRES-MS) were obtained with Thermo LTQ Orbitrap XL mass spectrometer (Thermo Fisher Scientific Inc., Waltham, MA, USA) combined to a Thermo U3000 high-performance liquid chromatography (HPLC) system (ESI technique, positive mode). The starting material 1 was prepared according to the literature [64]. 


\subsection{Chemistry}

4.2.1. General Procedure for the Synthesis of

3,6-dimethyl-1-phenyl-1,5-dihydro-4H-pyrazolo [3,4-d]pyrimidin-4-one 2

In a $100 \mathrm{~mL}$ three-necked flask, $4 \mathrm{mmol}$ of aminopyrazole $\mathbf{1}$ is introduced in $20 \mathrm{~mL}$ of acetic anhydride. Then $10 \mathrm{~mL}$ of phosphoric acid is added dropwise. The mixture is then brought to reflux for $3 \mathrm{~h}$ with magnetic stirring. The progress of the reaction is monitored by TLC (eluent 2: 8 ethyl acetate/chloroform) which showed the appearance of a new stain more polar than that of aminopyrazole 1 . After cooling, ice water is added to the reaction crude, the precipitated solid was filtered, washed with cold ether, dried, and then recrystallized from ethanol to give pyrimidinone 2 .

Yield: 79\%, mp: $277-279{ }^{\circ} \mathrm{C}$. ES-HRMS [M+H] $]^{+}$calcd. for $\left(\mathrm{C}_{13} \mathrm{H}_{13} \mathrm{~N}_{4} \mathrm{O}\right)^{+}:$: 241.1084, found: $241.1083 .{ }^{1} \mathrm{H}$ NMR $\left(400 \mathrm{MHz}, \mathrm{DMSO}-d_{6}\right): \delta(\mathrm{ppm})=2.39\left(\mathrm{~s}, 3 \mathrm{H}, \mathrm{H}_{3}-12\right), 2.50(\mathrm{~s}$, $\left.3 \mathrm{H}, \mathrm{H}_{3}-13\right), 7.34-8.03$ (m, 5H, H-Ar), 12.22 (brs, $\left.1 \mathrm{H}, \mathrm{NH}\right) .{ }^{13} \mathrm{C}$ NMR (100 MHz, DMSO- $\left.d_{6}\right)$ : $\delta(\mathrm{ppm})=13.3,21.5,103.7,121.3,126.4,129.1,138.4,145.7,152.9,158.59,158.65$.

4.2.2. General Procedure for the Synthesis of Ethyl

2-(3,6-dimethyl-4-oxo-1-phenyl-1,4-dihydro-5H-pyrazolo[3,4-d]pyrimidin-5-yl)acetate 3

Equimolar solution $1 \mathrm{mmol}$ of pyrimidinone 2, anhydrous potassium carbonate and ethyl chloroacetate was refluxed in dry dimethylformamide (DMF) $(60 \mathrm{~mL})$ with continuous stirring for $6 \mathrm{~h}$, into a three-necked flask of $100 \mathrm{~mL}$. Once the starting material is gone, the reaction mixture was then cooled and poured into cold water. Then, the formed precipitate was filtered off, washed with water, dried, and recrystallized from ethanol to give the ester 3.

Yield: $75 \%$, mp: $156-158{ }^{\circ} \mathrm{C}$. ES-HRMS [M+H] $]^{+}$calcd. for $\left(\mathrm{C}_{17} \mathrm{H}_{19} \mathrm{~N}_{4} \mathrm{O}_{3}\right)^{+}: 327.1452$, found: $327.1450 .{ }^{1} \mathrm{H}$ NMR $\left(400 \mathrm{MHz}, \mathrm{DMSO}-d_{6}\right): \delta(\mathrm{ppm})=1.22\left(\mathrm{t}, 3 \mathrm{H}, J=7 \mathrm{~Hz}, \mathrm{H}_{3}-15\right)$, $2.58\left(\mathrm{~s}, 3 \mathrm{H}, \mathrm{H}_{3}-12\right), 2.62\left(\mathrm{~s}, 3 \mathrm{H}, \mathrm{H}_{3}-13\right), 4.19\left(\mathrm{q}, 2 \mathrm{H}, J=6.96 \mathrm{~Hz}, \mathrm{H}_{2}-14\right), 5.16\left(\mathrm{~s}, 2 \mathrm{H}, \mathrm{H}_{2}-\mathrm{1}^{\prime}\right)$, 7.32-8.15 (m, 5H, H-Ar). ${ }^{13} \mathrm{C}$ NMR $\left(100 \mathrm{MHz}\right.$, DMSO- $\left.d_{6}\right): \delta(\mathrm{ppm})=13.90,14.03,25.9,60.8$, $62.8,100.6,120.6,126.2,129.2,138.5,142.4,155.8,162.5,165.4,167.8$.

4.2.3. General Procedure for the Synthesis of 2-(3,6-dimethyl-4-oxo-1-phenyl-1,4-dihydro5H-pyrazolo[3,4-d]pyrimidin-5-yl)acetohydrazide 4

The previously synthesized ester $\mathbf{3}$ was treated with an excess of hydrazine hydrate in ethanol at room temperature for 1-2 $\mathrm{h}$ until a white precipitate formed. The solid obtained was filtered, washed with ethanol, and dried to obtain compound 4.

Yield: $65 \%$, mp: $166-168{ }^{\circ} \mathrm{C}$. ES-HRMS [M+H] $]^{+}$calcd. for $\left(\mathrm{C}_{15} \mathrm{H}_{17} \mathrm{~N}_{6} \mathrm{O}_{2}\right)^{+}: 313.1408$, found: $313.1406 .{ }^{1} \mathrm{H}$ NMR (400 MHz, DMSO- $d_{6}$, mixture of isomers): $\delta(\mathrm{ppm})=2.51(\mathrm{~s}$, $\left.3 \mathrm{H}, \mathrm{H}_{3}-12\right), 2.53\left(\mathrm{~s}, 2.6 \mathrm{H}, \mathrm{H}_{3}-13\right), 2.59\left(\mathrm{~s}, 0.4 \mathrm{H}, \mathrm{H}_{3}-13\right), 4.34\left(\mathrm{~s}, 2 \mathrm{H},-\mathrm{NH}_{2}\right), 4.72\left(\mathrm{~s}, 2 \mathrm{H}, \mathrm{H}-1^{\prime}\right)$, 7.27-8.17 (m, 5H, H-Ar), 9.44 (s, 1H, NH). ${ }^{13} \mathrm{C}$ NMR (100 MHz, DMSO- $\left.d_{6}\right): \delta(\mathrm{ppm})=13.2$, 23.47, 23.59, 44.2, 102.9, 120.3, 121.1, 126.5, 128.9, 129.1, 138.3, 145.9, 150.8, 157.7, 159.9, 166.2 .

\subsubsection{General Procedure for the Synthesis of Derivatives $\mathbf{5 a - h}$}

An equimolar solution $(1 \mathrm{mmol})$ of hydrazide 4 and arylaldehyde in the presence of a few drops of hydrochloric acid was heated under reflux of ethanol $(15 \mathrm{~mL})$ for $9 \mathrm{~h}$. The reaction mixture was cooled to room temperature and the solvent was removed in vacuo and the obtained residue was purified by silica gel chromatography (petroleum ether/ethyl acetate, 65:35) to give compounds $\mathbf{5 a}-\mathbf{h}$.

As displaying an amide and an imine functions within the same structure, compounds 5a-h may exist as (a) $E / Z$ stereoisomers about the $\mathrm{C}=\mathrm{N}$ bond of hydrazone moiety and (b) cis/trans amide bond conformers. As $\mathrm{N}$-acyl substituted hydrazones are present in solution mainly as the $E$ stereoisomer $[65,66]$, the observed duplication of some ${ }^{1} \mathrm{H}$ and ${ }^{13} \mathrm{C}$ signals in NMR spectra of compounds $5 \mathbf{a}-\mathbf{h}$ (e.g., the methylene group at $\mathrm{C}-1^{\prime}$ and the imine function at $C-5^{\prime}$ ) can be generally attributed to the presence of cis / trans amide conformers [56,57]. Only compound $\mathbf{5 c}$ appeared to be present as a mixture of $E / Z$ stereoisomers and cis/trans amide conformers, according to NMR data. 
(E)-2-(3,6-dimethyl-4-oxo-1-phenyl-1,4-dihydro-5H-pyrazolo[3,4-d]pyrimidin-5-yl)-N'-(4 -(dimethylamino)benzylidene)acetohydrazide $\mathbf{5 a}$

Yield: $60 \%$, mp: $258-260{ }^{\circ} \mathrm{C}$. ES-HRMS $[\mathrm{M}+\mathrm{H}]^{+}$calcd. for $\left(\mathrm{C}_{24} \mathrm{H}_{26} \mathrm{~N}_{7} \mathrm{O}_{2}\right)^{+}: 444.2142$, found: 444.2139. ${ }^{1} \mathrm{H}$ NMR (400 MHz, DMSO- $d_{6}$, mixture of isomers): $\delta(\mathrm{ppm})=2.52(\mathrm{~s}$, $\left.3 \mathrm{H}, \mathrm{H}_{3}-12\right), 2.56\left(\mathrm{~s}, 2.4 \mathrm{H}, \mathrm{H}_{3}-13\right), 2.59\left(\mathrm{~s}, 0.6 \mathrm{H}, \mathrm{H}_{3}-13\right), 2.97\left(\mathrm{~s}, 1.8 \mathrm{H}, \mathrm{H}_{3}-\mathrm{a} / \mathrm{b}\right), 2.98(\mathrm{~s}, 4.2 \mathrm{H}$, $\left.\mathrm{H}_{3}-\mathrm{a} / \mathrm{b}\right), 4.85\left(\mathrm{~s}, 0.4 \mathrm{H}, \mathrm{H}_{2}-1^{\prime}\right), 5.28\left(\mathrm{~s}, 1.6 \mathrm{H}, \mathrm{H}_{2}-1^{\prime}\right), 6.74-8.08$ (m, 9H, H-Ar), $7.94(\mathrm{~s}, 0.7 \mathrm{H}$, $\left.\mathrm{H}-5^{\prime}\right), 8.08$ (s, 0.3H, H-5'), 11.56 (s, 0.9H, NH), 12.34 (s, 0.1H, NH). ${ }^{13} \mathrm{C}$ NMR (100 MHz, DMSO- $\left.d_{6}\right): \delta(\mathrm{ppm})=13.2,13.3,23.58,23.76,40.8,45.6,102.9,111.8,121.15,121.26,121.3$, 126.6, 128.3, 129.1, 129.2, 138.3, 145.3, 145.9, 150.9, 151.5, 157.8, 158.7, 160.0, 167.5.

(E)-2-(3,6-dimethyl-4-oxo-1-phenyl-1,4-dihydro-5H-pyrazolo[3,4-d]pyrimidin-5-yl)-N'-(4 -methoxybenzylidene)acetohydrazide $\mathbf{5 b}$

Yield: $75 \%$, mp: $246-248{ }^{\circ} \mathrm{C}$. ES-HRMS $[\mathrm{M}+\mathrm{H}]^{+}$calcd. for $\left(\mathrm{C}_{23} \mathrm{H}_{23} \mathrm{~N}_{6} \mathrm{O}_{3}\right)^{+}: 431.1826$, found: $431.1826{ }^{1} \mathrm{H}$ NMR $\left(400 \mathrm{MHz}, \mathrm{DMSO}-d_{6}\right.$, mixture of isomers): $\delta(\mathrm{ppm})=2.52(\mathrm{~s}, 3 \mathrm{H}$, $\left.\mathrm{H}_{3}-12\right), 2.56\left(\mathrm{~s}, 2.6 \mathrm{H}, \mathrm{H}_{3}-13\right), 2.59\left(\mathrm{~s}, 0.4 \mathrm{H}, \mathrm{H}_{3}-13\right), 3.80\left(\mathrm{~s}, 0.8 \mathrm{H}, \mathrm{H}_{3}-14\right), 3.81\left(\mathrm{~s}, 2.2 \mathrm{H}, \mathrm{H}_{3}-14\right)$, $4.88\left(\mathrm{~s}, 0.5 \mathrm{H}, \mathrm{H}_{2}-1^{\prime}\right), 5.30\left(\mathrm{~s}, 1.5 \mathrm{H}, \mathrm{H}_{2}-1^{\prime}\right), 7.02-8.06(\mathrm{~m}, 9 \mathrm{H}, \mathrm{H}-\mathrm{Ar}), 8.06\left(\mathrm{~s}, 1 \mathrm{H}, \mathrm{H}-5^{\prime}\right), 11.77$ $(\mathrm{s}, 1 \mathrm{H}, \mathrm{NH}) .{ }^{13} \mathrm{C}$ NMR $\left(100 \mathrm{MHz}, \mathrm{DMSO}-d_{6}\right): \delta(\mathrm{ppm})=13.69,13.81,24.0,24.2$ 45.0, 55.8, 103.3, 114.8, 121.7, 127.0, 129.0, 129.2, 129.5, 127.6, 138.7, 144.8, 146.4, 151.4, 153.4, 158.3, $160.5,161.3,168.3$.

(E)-2-(3,6-dimethyl-4-oxo-1-phenyl-1,4-dihydro-5H-pyrazolo[3,4-d]pyrimidin-5-yl)-N-(4 -nitrobenzylidene)acetohydrazide $\mathbf{5 c}$

Yield: 78\%, mp: $244-246{ }^{\circ} \mathrm{C}$. ES-HRMS [M+H] $]^{+}$calcd. for $\left(\mathrm{C}_{22} \mathrm{H}_{20} \mathrm{~N}_{7} \mathrm{O}_{4}\right)^{+}: 446.1571$, found: 446.1567. ${ }^{1} \mathrm{H}$ NMR (400 MHz, DMSO- $d_{6}$, mixture of isomers): $\delta(\mathrm{ppm})=1.91(\mathrm{~s}$, 2.2H, $\left.\mathrm{H}_{3}-12\right), 1.93\left(\mathrm{~s}, 0.8 \mathrm{H}, \mathrm{H}_{3}-12\right), 1.95\left(\mathrm{~s}, 0.7 \mathrm{H}, \mathrm{H}_{3}-13\right), 1.99\left(\mathrm{~s}, 2.3 \mathrm{H}, \mathrm{H}_{3}-13\right), 2.52(\mathrm{~s}, 3 \mathrm{H}$, $\left.\mathrm{H}_{3}-12\right), 2.56\left(\mathrm{~s}, 2.6 \mathrm{H}, \mathrm{H}_{3}-13\right), 2.59\left(\mathrm{~s}, 0.4 \mathrm{H}, \mathrm{H}_{3}-13\right), 4.90\left(\mathrm{~s}, 0.5 \mathrm{H}, \mathrm{H}_{2}-1^{\prime}\right), 4.93\left(\mathrm{~s}, 0.3 \mathrm{H}, \mathrm{H}_{2}-1^{\prime}\right)$, $5.15\left(\mathrm{~s}, 1.5 \mathrm{H}, \mathrm{H}_{2}-1^{\prime}\right), 5.36\left(\mathrm{~s}, 0.8 \mathrm{H}, \mathrm{H}_{2}-1^{\prime}\right), 7.33-8.29(\mathrm{~m}, 18 \mathrm{H}, \mathrm{H}-\mathrm{Ar}), 8.3\left(\mathrm{~s}, 0.5 \mathrm{H}, \mathrm{H}-5^{\prime}\right), 8.5$ $\left(\mathrm{s}, 0.5 \mathrm{H}, \mathrm{H}^{\prime} 5^{\prime}\right), 10.52(\mathrm{~s}, 0.2 \mathrm{H}, \mathrm{NH}), 10.66(\mathrm{~s}, 0.8 \mathrm{H}, \mathrm{NH}), 12.16(\mathrm{~s}, 0.2 \mathrm{H}, \mathrm{NH}), 12.23(\mathrm{~s}, 0.8 \mathrm{H}$, $\mathrm{NH}) .{ }^{13} \mathrm{C}$ NMR $\left(100 \mathrm{MHz}, \mathrm{DMSO}-d_{6}\right): \delta(\mathrm{ppm})=13.2,13.3,23.48$ 23.56, 44.8, 102.9, 121.2, 124.0, 126.4, 127.9, 129.0, 129.1, 138.3, 145.6, 150.8, 152.2, 157.8, 158.7, 160.0, 168.2.

(E)-N'-(3,4-dimethoxybenzylidene)-2-(3,6-dimethyl-4-oxo-1-phenyl-1,4-dihydro-5H-pyrazolo[3,4 -d]pyrimidin-5-yl)acetohydrazide $5 \mathbf{d}$

Yield: $70 \%$, mp: $255-257^{\circ} \mathrm{C}$. ES-HRMS [M+H] ${ }^{+}$calcd. for $\left(\mathrm{C}_{24} \mathrm{H}_{25} \mathrm{~N}_{6} \mathrm{O}_{4}\right)^{+}: 461.1932$, found: $461.1929 .{ }^{1} \mathrm{H}$ NMR (400 MHz, DMSO- $d_{6}$, mixture of isomers): $(\mathrm{ppm})=2.52(\mathrm{~s}$, $\left.3 \mathrm{H}, \mathrm{H}_{3}-12\right), 2.56\left(\mathrm{~s}, 2.2 \mathrm{H}, \mathrm{H}_{3}-13\right), 2.59\left(\mathrm{~s}, 0.8 \mathrm{H}, \mathrm{H}_{3}-13\right), 3.80\left(\mathrm{~s}, 1 \mathrm{H}, \mathrm{H}_{3}-14 / 15\right), 3.82(\mathrm{~s}, 5 \mathrm{H}$, $\left.\mathrm{H}_{3}-14 / 15\right), 4.88\left(\mathrm{~s}, 0.5 \mathrm{H}, \mathrm{H}_{2}-1^{\prime}\right), 5.32\left(\mathrm{~s}, 1.5 \mathrm{H}, \mathrm{H}_{2}-1^{\prime}\right), 7.02-7.08(\mathrm{~m}, 8 \mathrm{H}, \mathrm{H}-\mathrm{Ar}), 7.99(\mathrm{~s}, 0.8 \mathrm{H}$, $\left.\mathrm{H}-5^{\prime}\right), 8.16\left(\mathrm{~s}, 0.2 \mathrm{H}, \mathrm{H}-5^{\prime}\right), 11.75(\mathrm{~s}, 1 \mathrm{H}, \mathrm{NH}) .{ }^{13} \mathrm{C} \mathrm{NMR}\left(100 \mathrm{MHz}, \mathrm{DMSO}-d_{6}\right): \delta(\mathrm{ppm})=13.2$, 13.3, 23.6, 44.6, 45.1, 55.4, 55.5, 102.8, 108.6, 111.5, 121.2, 121.4, 126.5, 129.0, 129.1, 138.2, $144.5,145.9,149.0,150.7,150.9,157.8,159.9,167.9$.

(E)-2-(3,6-dimethyl-4-oxo-1-phenyl-1,4-dihydro-5H-pyrazolo[3,4-d]pyrimidin-5-yl)-N'-(3-ethoxy -4-hydroxybenzylidene)acetohydrazide $5 \mathbf{e}$

Yield: $62 \%$, mp: $242-244{ }^{\circ} \mathrm{C}$. ES-HRMS [M+H] ${ }^{+}$calcd. for $\left(\mathrm{C}_{24} \mathrm{H}_{25} \mathrm{~N}_{6} \mathrm{O}_{4}\right)^{+}: 461.1932$, found: $461.1926 .{ }^{1} \mathrm{H}$ NMR (400 MHz, DMSO- $d_{6}$, mixture of isomers): $\delta(\mathrm{ppm})=1.35(\mathrm{t}$, $\left.J=6.95 \mathrm{~Hz}, 3 \mathrm{H}, \mathrm{H}_{3}-15\right), 2.52\left(\mathrm{~s}, 3 \mathrm{H}, \mathrm{H}_{3}-12\right), 2.56\left(\mathrm{~s}, 2.3 \mathrm{H}, \mathrm{H}_{3}-13\right), 2.59\left(\mathrm{~s}, 0.7 \mathrm{H}, \mathrm{H}_{3}-13\right), 4.08$ (q, J = 6.92 Hz, 2H, $\left.\mathrm{H}_{2}-14\right), 4.9\left(\mathrm{~s}, 0.5 \mathrm{H}, \mathrm{H}_{2}-1^{\prime}\right), 5.29\left(\mathrm{~s}, 1.5 \mathrm{H}, \mathrm{H}_{2}-1^{\prime}\right), 6.85-8.06$ (m, 8H, H-Ar), $7.94\left(\mathrm{~s}, 0.8 \mathrm{H}, \mathrm{H}-5^{\prime}\right), 8.06\left(\mathrm{~s}, 0.2 \mathrm{H}, \mathrm{H}-5^{\prime}\right), 9.48(\mathrm{~s}, 1 \mathrm{H}, \mathrm{OH}), 11.67(\mathrm{~s}, 1 \mathrm{H}, \mathrm{NH}) .{ }^{13} \mathrm{C} \mathrm{NMR}(100$ MHz, DMSO- $\left.d_{6}\right): \delta(\mathrm{ppm})=13.2,14.7,23.57,23.71,44.6,63.84,63.89,102.9,110.6,110.9$, $115.6,121.2,121.5,121.9,125.2,126.5,129.2,138.2,144.9,145.3,145.9,147.1,147.8,149.2$, $150.9,157.77,157.83,160.0,162.9,167.8$.

(E)-2-(3,6-dimethyl-4-oxo-1-phenyl-1,4-dihydro-5H-pyrazolo[3,4-d]pyrimidin-5-yl)-N'-(4 -fluorobenzylidene)acetohydrazide $\mathbf{5 f}$

Yield: $68 \%$, mp: $250-252^{\circ} \mathrm{C}$. ES-HRMS [M+H] ${ }^{+}$calcd. for $\left(\mathrm{C}_{22} \mathrm{H}_{20} \mathrm{FN}_{6} \mathrm{O}_{2}\right)^{+}: 419.1626$, found: 419.1626. ${ }^{1} \mathrm{H}$ NMR (400 MHz, DMSO- $d_{6}$, mixture of isomers): $\delta(\mathrm{ppm})=2.52(\mathrm{~s}$, $\left.3 \mathrm{H}, \mathrm{H}_{3}-12\right), 2.56\left(\mathrm{~s}, 2.5 \mathrm{H}, \mathrm{H}_{3}-13\right), 2.59$ (s, 0.5H, $\left.\mathrm{H}_{3}-13\right), 4.89$ (s, $\left.0.4 \mathrm{H}, \mathrm{H}_{2}-1^{\prime}\right), 5.32$ (s, 1.6H, $\left.\mathrm{H}_{2}-1^{\prime}\right), 7.27-8.24(\mathrm{~m}, 9 \mathrm{H}, \mathrm{H}-\mathrm{Ar}), 8.08\left(\mathrm{~s}, 1 \mathrm{H}, \mathrm{H}-5^{\prime}\right), 11.89$ (s, 1H, NH). ${ }^{13} \mathrm{C}$ NMR $(100 \mathrm{MHz}$, 
DMSO- $\left.d_{6}\right): \delta(\mathrm{ppm})=13.68,24.0,45.0,103.3,104.2,116.3,116.5,121.8,127.1,129.7,131.0$, $138.7,138.9,143.8,146.4,151.4,158.3,160.4,168.7$.

(E)-N'-(5-bromo-2-hydroxybenzylidene)-2-(3,6-dimethyl-4-oxo-1-phenyl-1,4-dihydro-5H -pyrazolo[3,4-d]pyrimidin-5-yl)acetohydrazide $5 \mathrm{~g}$

Yield: $64 \%$, mp: $253-255^{\circ} \mathrm{C}$. ES-HRMS $[\mathrm{M}+\mathrm{H}]^{+}$calcd. for $\left(\mathrm{C}_{22} \mathrm{H}_{20} \mathrm{BrN}_{6} \mathrm{O}_{3}\right)^{+}$: 495.0775, found: $495.0768 .{ }^{1} \mathrm{H}$ NMR (400 MHz, DMSO- $d_{6}$, mixture of isomers): $\delta(\mathrm{ppm})=2.52(\mathrm{~s}, 3 \mathrm{H}$, $\left.\mathrm{H}_{3}-12\right), 2.56\left(\mathrm{~s}, 2.2 \mathrm{H}, \mathrm{H}_{3}-13\right), 2.60\left(\mathrm{~s}, 0.8 \mathrm{H}, \mathrm{H}_{3}-13\right), 4.90\left(\mathrm{~s}, 1.4 \mathrm{H}, \mathrm{H}_{2}-1^{\prime}\right), 5.32\left(\mathrm{~s}, 0.6 \mathrm{H}, \mathrm{H}_{2}-1^{\prime}\right)$, 6.89-8.06 (m, 8H, H-Ar), 8.31 (s, 0.6H, H-5'), $8.43\left(\mathrm{~s}, 0.4 \mathrm{H}, \mathrm{H}-5^{\prime}\right), 10.44(\mathrm{~s}, 0.7 \mathrm{H}, \mathrm{OH}), 10.44$ $(\mathrm{s}, 0.3 \mathrm{H}, \mathrm{OH}), 11.84(\mathrm{~s}, 0.7 \mathrm{H}, \mathrm{NH}), 12.16(\mathrm{~s}, 0.3 \mathrm{H}, \mathrm{NH}) .{ }^{13} \mathrm{C}$ NMR $\left(100 \mathrm{MHz}, \mathrm{DMSO}-d_{6}\right)$ : $\delta(\mathrm{ppm})=13.2,23.6,23.7,44.7,48.6,102.9,110.5,110.9,118.5,121.3,122.5,126.6,127.7,129.1$, 130.1, 130.9, 133.6, 138.3, 139.7, 145.9, 150.9, 155.7, 156.3, 157.8, 160.0, 165.4, 168.1.

(E)-N'-(4-bromobenzylidene)-2-(3,6-dimethyl-4-oxo-1-phenyl-1,4-dihydro-5H-pyrazolo[3,4 -d]pyrimidin-5-yl)acetohydrazide $\mathbf{5 h}$

Yield: $72 \%$, mp: $248-250{ }^{\circ} \mathrm{C}$. ES-HRMS [M+H] ${ }^{+}$calcd. for $\left(\mathrm{C}_{22} \mathrm{H}_{20} \mathrm{BrN}_{6} \mathrm{O}_{2}\right)^{+}: 479.0826$, found: $479.0821 .{ }^{1} \mathrm{H}$ NMR $\left(400 \mathrm{MHz}\right.$, DMSO- $d_{6}$, mixture of isomers): $\delta(\mathrm{ppm})=2.52(\mathrm{~s}, 3 \mathrm{H}$, $\left.\mathrm{H}_{3}-12\right), 2.56\left(\mathrm{~s}, 2.3 \mathrm{H}, \mathrm{H}_{3}-13\right), 2.59\left(\mathrm{~s}, 0.7 \mathrm{H}, \mathrm{H}_{3}-13\right), 4.89$ (s, $\left.0.4 \mathrm{H}, \mathrm{H}_{2}-1^{\prime}\right), 5.32\left(\mathrm{~s}, 1.6 \mathrm{H}, \mathrm{H}_{2}-1^{\prime}\right)$, 7.37-8.06 (m, 9H, H-Ar), 8.06 (s, 0.8H, H-5'), 8.22(s, 0.2H, H-5'), 11.94 (s, 1H, NH). ${ }^{13} \mathrm{C}$ NMR $\left(100 \mathrm{MHz}, \mathrm{DMSO}-d_{6}\right): \delta(\mathrm{ppm})=13.2,23.6,23.7,44.6,45.1,102.9,121.3,123.36,123.45,126.6$, $128.8,129.0,129.2$, 131.8, 133.2, 138.2, 143.3, 125.9, 146.1, 150.9, 157.8, 159.9, 163.5, 168.3.

\subsection{Cell Viability Assays}

Real time monitoring of cell viability was performed using the Real-Time Cell Analyzer (RTCA) xCELLigence System (ACEA Biosciences, San Diego, CA, USA), as previously reported [67]. MCF-7 and NHDF cells were cultured in Dulbecco's Modified Eagle's medium (DMEM) high glucose ( $4.5 \mathrm{~g} / \mathrm{L})$ medium, supplemented with $10 \%$ fetal bovine serum, penicillin-streptomycin (100 U/mL), and $2 \mathrm{mM}$ L-glutamine. MCF-7 and NHDF cells were seeded at a cell density of 3000 cells/well and 2000 cells/well, respectively. During the exponential growth phase, approximately $24 \mathrm{~h}$ after seeding, medium was removed, and cells were treated with medium containing the synthetic compounds at the indicated concentrations. All compounds were dissolved in DMSO to prepare 20- or 10-mM stock solutions and further diluted in culture medium to perform antiproliferative assays. In all experiments, the final concentration of DMSO did not exceed $0.5 \%$, which was shown to be well tolerated with no obvious toxic effects to cells.

Growth inhibitory effects of synthetic compounds are reported as cell index values relative to controls treated with $0.5 \%$ DMSO vehicle. Cell index values were normalized just after the start of treatment to have normalized cell index values (NCI). Growth curves were generated by measuring normalized cell index variations. NCI values and real-time NCI traces were obtained through the RTCA-integrated software (version 2.0.0.1301, ACEA Biosciences, San Diego, CA, USA).

Dose-response curves for $\mathbf{5 a}, \mathbf{5 e}, \mathbf{5 g}$, and $5 \mathrm{~h}$ were modeled using the variable slope sigmoid Hill equation, to determine $\mathrm{IC}_{50}$ values against MCF7 and NHDF cells after 24-h and 48-h drug treatments, respectively. As NHDF have longer doubling time than MCF7 cells ( $42.6 \mathrm{~h} \pm 1.7$ versus $21.3 \mathrm{~h} \pm 0.2$ ), cytotoxicity in fibroblasts was evaluated within a wider time window, thereby allowing cells to complete at least one full cell cycle. Doseresponse curves and $\mathrm{IC}_{50}$ values were calculated using the GraphPad Prism Software Version 5 (GraphPad Software Inc., San Diego, CA, USA).

\subsection{Apoptosis Assay and Cell Cycle Analysis}

After $24 \mathrm{~h}$ exposure to $\mathrm{IC}_{50}$ concentrations of $\mathbf{5 a}, \mathbf{5 e}, \mathbf{5 g}$, and $5 \mathbf{h}, \mathrm{MCF}-7$ cells were collected and stained with annexin-V-fluorescein isothiocyanate (FITC) and propidium iodide, using the FITC Annexin V Apoptosis Detection kit I (Becton Dickinson, BD, Franklin, NJ, USA) for detection of apoptotic and necrotic cells by flow cytometry, as previously reported [68]. Samples were prepared according to manufacturer's protocol. 
For analysis of cell cycle distribution, MCF-7 cells (a) were incubated for $24 \mathrm{~h}$ with $5 \mathbf{a}, \mathbf{5 e}, \mathbf{5 g}$, and $\mathbf{5 h}$ at their $\mathrm{IC}_{50}$ concentrations, (b) permeabilized with $70 \%$ cold ethanol for $1 \mathrm{~h}$, and (c) stained for $30 \mathrm{~min}$ with a calcium and magnesium-free PBS solution containing $50 \mu \mathrm{g} / \mathrm{mL}$ propidium iodide (Sigma Aldrich, St. Louis, MO, USA) and $10 \mu \mathrm{g} / \mathrm{mL}$ RNase A (EuroClone S.p.a., Pero, MI, Italy).

Flow cytometry analyses were performed by using a NAVIOS flow cytometer and acquired data elaborated by Kaluza software (Beckman Coulter, Brea, CA, USA). Ten thousand events were acquired for each analyzed sample, and at least three independent experiments were carried out.

\subsection{Molecular Docking Procedure}

The optimization of all the geometries of scaffolds was performed with Gaussian 09 semi-empirical PM3 force-field method [69]. The co-crystal structure of 'erlotinib' with EGFR of PDB (PDB: 1M17) was obtained from the RSCB protein data bank. [70] Docking studies were performed using Autodock 4.2 software [71]. The visualization and analysis of interactions were performed using Pymol, version 0.99 [72].

\subsection{Physicochemical Studies}

\subsubsection{Synthesis of Oligomers}

Oligonucleotides have been synthesized on an ABI 394 DNA/RNA synthesizer (Applied Biosystem, Inc., Waltham, MA, USA) by using the standard DNA synthesis protocol on solid phase at the 5- $\mu \mathrm{mol}$ scale [73]. In particular, the following DNA sequences have been synthesized: d(AGGGCGGTGTGGGAATAGGGAA) (KRAS 22RT), d(TAGGGTTAGGGTTAGGGTTAGGG) (Tel23), d(GGGCGCGGGAGGAATTGGGCGGG) (BCL2-G4), and d(CGAATTCGTTTTCGAATTCG) (hairpin duplex). After synthesis, the oligonucleotides were detached from the support and deprotected by treatment with concentrated aqueous ammonia at $55^{\circ} \mathrm{C}$ for $12 \mathrm{~h}$. The combined filtrates and washings were concentrated under reduced pressure, dissolved in water, and purified by highperformance liquid chromatography (HPLC) on a Nucleogel SAX column (MachereyNagel, 1000-8/46), using buffer A consisting of $20 \mathrm{mM} \mathrm{KH_{2 }} \mathrm{PO}_{/} / \mathrm{K}_{2} \mathrm{HPO}_{4}$ aqueous solution ( $\mathrm{pH} 7.0)$, containing $20 \%(\mathrm{v} / \mathrm{v}) \mathrm{CH}_{3} \mathrm{CN}$, buffer B consisting of $1 \mathrm{M} \mathrm{KCl}, 20 \mathrm{mM}$ $\mathrm{KH}_{2} \mathrm{PO}_{4} / \mathrm{K}_{2} \mathrm{HPO}_{4}$ aqueous solution ( $\mathrm{pH} 7.0$ ), containing $20 \%(v / v) \mathrm{CH}_{3} \mathrm{CN}$, and a linear gradient from $0 \%$ to $100 \% \mathrm{~B}$ for $30 \mathrm{~min}$ with a flow rate of $1 \mathrm{~mL} \mathrm{~min}{ }^{-1}$. The isolated oligomers were further desalted by Sep-pak cartridges C-18(Waters) and lyophilized. DNA samples were then dissolved in $20 \mathrm{mM}$ phosphate buffer (pH 7.0) containing $60 \mathrm{mM}$ $\mathrm{KCl}$ and $0.1 \mathrm{mM}$ EDTA. The concentration of oligonucleotides was determined by UV adsorption measurements at $90^{\circ} \mathrm{C}$ using molar extinction coefficient values $\varepsilon(\lambda=260 \mathrm{~nm})$ calculated by the nearest neighbor model [74]. All samples were heated at $90^{\circ} \mathrm{C}$ for $5 \mathrm{~min}$, gradually cooled to room temperature overnight, and finally incubated at $4{ }^{\circ} \mathrm{C}$ before data acquisition.

\subsubsection{Circular Dichroism (CD) Experiments}

Circular dichroism (CD) experiments were performed on a Jasco J-815 spectropolarimeter (JASCO Inc., Tokyo, Japan) equipped with a PTC-423S/15 Peltier temperature controller. All the spectra were recorded at $20^{\circ} \mathrm{C}$ in the wavelength range of $230-340 \mathrm{~nm}$ and averaged over three scans. The scan rate was $100 \mathrm{~nm} \mathrm{~min}^{-1}$, with a $4 \mathrm{~s}$ response and $1 \mathrm{~nm}$ bandwidth. Buffer baseline was subtracted from each spectrum. A $2 \mathrm{mM}$ oligonucleotide concentration was used. CD spectra of DNA/ligand mixtures were obtained by adding $10 \mathrm{~mol}$ equiv of ligands (stock solutions of ligands were $10 \mathrm{mM}$ in DMSO). The $\mathrm{CD}$ melting curves were obtained by following changes of $\mathrm{CD}$ signal at the wavelength of maximum intensity for the G4 sequences and at the wavelength of minimum intensity for the hairpin duplex (264 nm for KRAS 22RT and BCL2-G4, $287 \mathrm{~nm}$ for Tel23, $251 \mathrm{~nm}$ for hairpin duplex). The experiments were carried out in the $20-100{ }^{\circ} \mathrm{C}$ range at $1{ }^{\circ} \mathrm{C} \mathrm{min}$ -1 heating rate and were recorded in the absence and presence of ligands (10 mol equiv) 
added to the folded DNA structures. The melting temperatures $\left(T_{m}\right)$ were determined from curve fit using Origin 7.0 software. $\Delta T_{\mathrm{m}}$ values were determined as the difference in the melting temperature of DNA structures with and without ligands. Each experiment was performed in duplicate, and the reported values averaged.

Supplementary Materials: The following are available online at https:/ /www.mdpi.com/1422-0 067/22/5/2742/s1, Figure S1. Real time monitoring of NHDF cell viability, Figure S2: Binding mode of ester 3 in the erlotinib binding site of EGFR (PDB:1M17), Figure S3: CD spectra of (a) KRAS 22RT, (b) BCL2-G4, (c) Tel 23, and (d) Hairpin duplex, Figure S4: ${ }^{1} \mathrm{H}$ NMR spectrum of compound 2, Figure S5: ${ }^{13} \mathrm{C}$ NMR spectrum of compound 2, Figure S6: ${ }^{1} \mathrm{H}$ NMR spectrum of compound 3, Figure S7: ${ }^{13} \mathrm{C}$ NMR spectrum of compound 3, Figure S8: ${ }^{1} \mathrm{H}$ NMR spectrum of compound 4, Figure S9: ${ }^{13} \mathrm{C}$ NMR spectrum of compound 4, Figure S10: ${ }^{1} \mathrm{H}$ NMR spectrum of compound $5 \mathbf{a}$, Figure S11: ${ }^{13} \mathrm{C}$ NMR spectrum of compound $\mathbf{5 a}$, Figure S12: ${ }^{1} \mathrm{H}$ NMR spectrum of compound $\mathbf{5 b}$, Figure S13: ${ }^{13} \mathrm{C}$ NMR spectrum of compound $\mathbf{5 b}$, Figure S14: ${ }^{1} \mathrm{H}$ NMR spectrum of compound $\mathbf{5} \mathbf{c}$, Figure S15: ${ }^{13} \mathrm{C}$ NMR spectrum of compound $\mathbf{5 c}$, Figure S16: ${ }^{1} \mathrm{H}$ NMR spectrum of compound $\mathbf{5 d}$, Figure S17: ${ }^{13} \mathrm{C}$ NMR spectrum of compound 5 d, Figure S18: ${ }^{1} \mathrm{H}$ NMR spectrum of compound $\mathbf{5 e}$, Figure S19: ${ }^{13} \mathrm{C}$ NMR spectrum of compound $5 e$, Figure S20: ${ }^{1} \mathrm{H}$ NMR spectrum of compound $5 \mathrm{f}$, Figure S21: ${ }^{13} \mathrm{C}$ NMR spectrum of compound $5 \mathbf{f}$, Figure S22: ${ }^{1} \mathrm{H}$ NMR spectrum of compound $\mathbf{5 g}$, Figure S23: ${ }^{13} \mathrm{C}$ NMR spectrum of compound $5 \mathrm{~g}$, Figure S24: ${ }^{1} \mathrm{H}$ NMR spectrum of compound $\mathbf{5 h}$, Figure S25: ${ }^{13} \mathrm{C}$ NMR spectrum of compound 5h, Figure S26: HR-ESI-MS spectrum of compound 2, Figure S27: HR-ESI-MS spectrum of compound 3, Figure S28: HR-ESI-MS spectrum of compound 4, Figure S29: HR-ESI-MS spectrum of compound 5a, Figure S30: HR-ESI-MS spectrum of compound $\mathbf{5 b}$, Figure S31: HR-ESI-MS spectrum of compound 5c, Figure S32: HR-ESI-MS spectrum of compound 5d, Figure S33: HR-ESI-MS spectrum of compound 5e, Figure S34: HR-ESI-MS spectrum of compound $5 \mathbf{f}$, Figure S35: HR-ESI-MS spectrum of compound $5 g$, Figure S36: HR-ESI-MS spectrum of compound 5 h.

Author Contributions: Conceptualization, G.D.S., V.C., and H.B.J.; methodology, C.G. and H.B.J.; validation, A.C., I.L., and G.E.; investigation, M.H., G.D.S., F.D., and A.R.; resources, C.G., H.B.J., and V.C.; data curation, G.D.S., A.C., C.G., A.R., and H.B.J.; writing-original draft preparation, M.H., G.D.S., H.B.J., and F.D.; writing-review and editing, C.G., H.B.J., and V.C.; visualization, I.L.; supervision, C.G., H.B.J., and V.C.; project administration, H.B.J. and V.C.; funding acquisition, H.B.J. and V.C. All authors have read and agreed to the published version of the manuscript.

Funding: Biological studies were funded by the Italian Ministry of Health, by Current Research Funds to IRCCS-CROB, Rionero in Vulture, Potenza, Italy and OncoLab, Regione Campania, PO FESR 2014-2020, O.S. Project “Campania Oncoterapie” No. BG1G18000470007, Italy.

Institutional Review Board Statement: Not applicable.

Informed Consent Statement: Not applicable.

Data Availability Statement: Not applicable.

Acknowledgments: We thank the Laboratory of Structural Analysis, at the Department of Pharmacy, University of Naples Federico II for helpful collaboration. G.C. also acknowledges funding from Italian Association for Cancer Research (AIRC) under IG 2019 (Project ID 23198).

Conflicts of Interest: The authors declare no conflict of interest.

\section{References}

1. Torre, L.A.; Bray, F.; Siegel, R.L.; Ferlay, J.; Lortet-Tieulent, J.; Jemal, A. Global cancer statistics, 2012. CA Cancer J. Clin. 2015, 65, 87-108. [CrossRef]

2. Cancer-World Health Organization. Available online: http://www.who.int/mediacentre/factsheets/fs297/en/ (accessed on 5 January 2021).

3. Strickaert, A.; Saiselet, M.; Dom, G.; De Deken, X.; Dumont, J.E.; Feron, O.; Sonveaux, P.; Maenhaut, C. Cancer heterogeneity is not compatible with one unique cancer cell metabolic map. Oncogene 2017, 36, 2637-2642. [CrossRef] [PubMed]

4. Caso, A.; Laurenzana, I.; Lamorte, D.; Trino, S.; Esposito, G.; Piccialli, V.; Costantino, V. Smenamide A Analogues. Synthesis and Biological Activity on Multiple Myeloma Cells. Mar. Drugs. 2018, 16, 206. [CrossRef]

5. Caso, A.; Mangoni, A.; Piccialli, G.; Costantino, V.; Piccialli, V. Studies toward the Synthesis of Smenamide A, an Antiproliferative Metabolite from Smenospongia aurea: Total Synthesis of ent-Smenamide A and 16-epi-Smenamide A. ACS Omega 2017, 2, 1477-1488. [CrossRef] 
6. Esposito, G.; Della Sala, G.; Teta, R.; Caso, A.; Bourguet-Kondraki, M.L.; Pawlik, J.R.; Mangoni, A.; Costantino, V. Chlorinated Thiazole-Containing Polyketide-Peptides from the Caribbean Sponge Smenospongia conulosa: Structure Elucidation on Microgram Scale. Eur. J. Org. Chem. 2016, 2871-2875. [CrossRef]

7. Della Sala, G.; Hochmuth, T.; Costantino, V.; Teta, R.; Gerwick, W.; Gerwick, L.; Piel, J.; Mangoni, A. Polyketide Genes in the Marine Sponge Plakortis simplex: A New Group of Mono-Modular Type-I Polyketide Synthases from Sponge Symbionts. Environ. Microbiol. Rep. 2013, 5, 809-818. [CrossRef]

8. Costantino, V.; Fattorusso, E.; Imperatore, C.; Mangoni, A.; Teta, R. Glycolipids from Sponges. Part 21. Amphiceramide A and B, Novel Glycosphingolipids from the Marine Sponge Amphimedon compressa. Eur. J. Org. Chem. 2009, 2112-2119. [CrossRef]

9. Britstein, M.; Devescovi, G.; Handley, K.; Malik, A.; Haber, M.; Saurav, K.; Teta, R.; Costantino, V.; Burgsdorf, I.; Gilbert, J.; et al. A New N-Acyl homoserine lactone synthase in an uncultured symbiont of the red sponge Theonella swinohei. Appl. Environ. Microbiol. 2016, 82, 1274-1285. [CrossRef] [PubMed]

10. Teta, R.; Della Sala, G.; Renga, B.; Mangoni, A.; Fiorucci, S.; Costantino, V. Chalinulasterol, a chlorinated steroid disulfate from the caribbean sponge Chalinula molitba. Evaluation of its role as PXR receptor modulator. Mar. Drugs 2012, 10, 1383-1390. [CrossRef]

11. Teta, R.; Marteinsson, V.T.; Longeon, A.; Klonowski, A.M.; Groben, R.; Bourguet-Kondracki, M.-L.; Costantino, V.; Mangoni, A. Thermoactinoamide A, an antibiotic lipophilic cyclopeptide from the icelandic thermophilic bacterium thermoactinomyces vulgaris. J. Nat. Prod. 2017, 80, 2530-2535. [CrossRef]

12. Rees, D.C.; Congreve, M.; Murray, C.W.; Carr, R. Fragment-based lead discovery. Nat. Rev. Drug. Discov. $2004,3,660-672$. [CrossRef] [PubMed]

13. Wang, J.M.; Hou, T.J. Drug and drug candidate building block analysis. J. Chem. Inf. Model. 2010, 50, 55-67. [CrossRef] [PubMed]

14. Bhat, B.A.; Dhar, K.L.; Puri, S.C.; Saxena, A.K.; Shanmugavel, M.; Qazi, G.N. Synthesis and biological evaluation of chalcones and their derived pyrazoles as potential cytotoxic agents. Bioorg. Med. Chem. Lett. 2005, 15, 3177-3180. [CrossRef]

15. Nossier, E.S.; Fahmy, H.H.; Khalifa, N.M.; El-Eraky, W.I.; Baset, M.A. Design and Synthesis of Novel Pyrazole-Substituted Different Nitrogenous Heterocyclic Ring Systems as Potential Anti-Inflammatory Agents. Molecules 2017, 22, 512-528. [CrossRef] [PubMed]

16. Riyadh, S.M.; Farghaly, T.A.; Abdallah, M.A.; Abdalla, M.M.; Abd El-Aziz, M.R. New Pyrazoles Incorporating Pyrazolylpyrazole Moiety: Synthesis, anti- HCV and Antitumor Activity. Eur. J. Med. Chem. 2010, 45, 1042-1050. [CrossRef]

17. Zhang, W.; Holyoke, C.W.; Barry, J.; Cordova, D.; Leighty, R.M.; Tong, M.T.; Hughes, K.A.; Pahutski, T.F.; Xu, M.; Briddell, T.A.; et al. Mesoionicpyrido[1,2-a]pyrimidinones: Discovery of triflumezopyrim as a potent hopper insecticide. Bioorg. Med. Chem. Lett. 2017, 27, 16-20. [CrossRef] [PubMed]

18. Wang, R.; Chai, W.M.; Yang, Q.; Wei, M.K.; Peng, Y. 2-(4-Fluorophenyl)-quinazolin- 4(3H)-one as a novel tyrosinase inhibitor: Synthesis, inhibitory activity, and mechanism. Bioorg. Med. Chem. 2016, 24, 4620-4625. [CrossRef]

19. Patel, N.B.; Patel, J.C. Synthesis and antimicrobial activity of Schiff bases and 2-azetidinones derived from quinazolin-4(3H)-one. Arab. J. Chem. 2011, 4, 403-411. [CrossRef]

20. Nagwa, M.A.G.; Hanan, H.G.; Riham, M.Y.; Nehad, A.E.S. Synthesis and antitumor activity of some 2,3-disubstituted quinazolin4(3H)- ones and 4,6-disubstituted-1,2,3,4-tetrahydroquinazolin-2H-ones. Eur. J. Med. Chem. 2010, 45, 6058-6067. [CrossRef]

21. El-Mekabaty, A. Synthesis and Antioxidant Activity of Some New Heterocycles Incorporating the Pyrazolo[3,4-d]pyrimidin-4-one Moiety. Chem. Heterocycl. Compd. 2015, 50, 1698-1706. [CrossRef]

22. De Vita, D.; Pandolfi, F.; Cirilli, R.; Scipione, L.; Di Santo, R.; Friggeri, L.; Mori, M.; Fiorucci, D.; Maccari, G.; Christopher, R.S.A.; et al. Discovery of in vitro antitubercular agents through in silico ligand-based approaches. Eur. J. Med. Chem. 2016, 121, 169-180. [CrossRef]

23. Gong, P.; Zhao, Y.F.; Wang, D. Synthesis and vasodilatory activities of new pyrazolo[3,4- d]pyrimidin-4-one derivatives. Chin. Chem. Lett. 2002, 13, 613-616.

24. Kumar, R.; Joshi, Y.C. Synthesis, antimicrobial and antifungal activities of novel 1H-1,4-diazepines containing pyrazolopyrimidinone moiety. J. Chem. Sci. 2009, 121, 497-502. [CrossRef]

25. Baviskar, A.T.; Banerjee, U.C.; Gupta, M.; Singh, R.; Kumar, S.; Gupta, M.K.; Kumar, S.; Raut, S.K.; Khullar, M.; Singh, S.; et al. Synthesis of imine-pyrazolopyrimidinones and their mechanistic interventions on anticancer activity. Bio. Org. Med. Chem. 2013, 21, 5782-5793. [CrossRef] [PubMed]

26. El-Mekabaty, A.; Etman, H.A.; Mosbah, A.; Fadda, A.A. Synthesis, In Vitro Cytotoxicity and Bleomycin-Dependent DNA Damage Evaluation of Some Heterocyclic-Fused Pyrimidinone Derivatives. ChemistrySelect 2020, 5, 4856-4861. [CrossRef]

27. Hassan, G.S.; Kadry, H.H.; Abou-Seri, S.M.; Ali, M.M.; Mahmoud, A.E.E. Synthesis and in vitro cytotoxic activity of novel pyrazolo[3,4-d]pyrimidines and related pyrazolehydrazones toward breast adenocarcinoma MCF-7 cell line. Bioorg. Med. Chem. 2011, 19, 6808-6817. [CrossRef]

28. Reddy, G.L.; Guru, S.K.; Srinivas, M.; Pathania, A.S.; Mahajan, P.; Nargotra, A.; Bhushan, S.; Vishwakarma, R.A.; Sawant, S.D. Synthesis of 5-substituted-1H-pyrazolo[4,3-d]pyrimidin-7(6H)-one analogs and their biological evaluation as anticancer agents: mTOR inhibitors. Eur. J. Med. Chem. 2014, 80, 201-208. [CrossRef]

29. Salar, U.; Taha, M.; Khan, K.M.; Ismail, N.H.; Imran, S.; Perveen, S.; Gul, S.; Wadood, A. Syntheses of new 3-thiazolyl coumarin derivatives, in vitro $\alpha$-glucosidase inhibitory activity, and molecular modeling studies. Eur. J. Med. Chem. 2016, 122, 196-204. [CrossRef]

30. Garkani-Nejad, Z.; Ahmadi-Roudi, B. Modeling the antileishmanial activity screening of 5-nitro-2-heterocyclic benzylidene hydrazides using different chemometrics methods. Eur. J. Med. Chem. 2010, 45, 719-726. [CrossRef] [PubMed] 
31. Walcourt, A.; Loyevsky, M.; Lovejoy, D.B.; Gordeuk, V.R.; Richardson, D.R. Novel aroylhydrazone and thiosemicarbazone iron chelators with anti-malarial activity against chloroquine-resistant and -sensitive parasites. Int. J. Biochem. Cell Biol. 2004, 36, 401-407. [CrossRef]

32. Mohareb, R.M.; Fleita, D.H.; Sakka, O.K. Novel synthesis of hydrazide-hydrazone derivatives and their utilization in the synthesis of coumarin, pyridine, thiazole and thiophene derivatives with antitumor activity. Molecules 2010, 16, 16-27. [CrossRef] [PubMed]

33. Bernardino, A.; Gomes, A.; Charret, K.; Freitas, A.; Machado, G.; Canto-Cavalheiro, M.; Leon, L.; Amaral, V. Synthesis and leishmanicidal activities of 1-(4-X-phenyl)-N'-[(4-Y-phenyl)methylene]-1H-pyrazole-4-carbohydrazides. Eur. J. Med. Chem. 2006, 41, 80-87. [CrossRef]

34. Gürsoy, A.; Karali, N. Synthesis and primary cytotoxicity evaluation of 3-[[(3-phenyl-4(3H)-quinazolinone-2-yl)mercaptoacetyl] hydrazono]-1H-2-indolinones. Eur. J. Med. Chem. 2003, 38, 633-643. [CrossRef]

35. Carvalho, J.; Mergny, J.L.; Salgado, G.F.; Queiroz, J.A.; Cruz, C. G-quadruplex, Friend or Foe: The Role of the G-quartet in Anticancer Strategies. Trends Mol. Med. 2020, 26, 848-861. [CrossRef] [PubMed]

36. Caterino, M.; D’Aria, F.; Kustov, A.V.; Belykh, D.V.; Khudyaeva, I.S.; Starseva, O.M.; Berezin, D.B.; Pylina, Y.I.; Usacheva, T.; Amato, J.; et al. Selective binding of a bioactive porphyrin-based photosensitizer to the G-quadruplex from the KRAS oncogene promoter. Int. J. Biol. Macromol. 2020, 145, 244-251. [CrossRef] [PubMed]

37. Pagano, B.; Fotticchia, I.; De Tito, S.; Mattia, C.A.; Mayol, L.; Novellino, E.; Randazzo, A.; Giancola, C. Selective binding of distamycin a derivative to G-quadruplex structure [d(TGGGGT)]4. J. Nucleic Acids 2010. [CrossRef]

38. Maennling, A.E.; Tur, M.K.; Niebert, M.; Klockenbring, T.; Zeppernick, F.; Gattenlöhner, S.; Meinhold-Heerlein, I.; Hussain, A.F. Molecular Targeting Therapy against EGFR Family in Breast Cancer: Progress and Future Potentials. Cancers 2019, 11, 1826. [CrossRef] [PubMed]

39. Gazdar, A.F. Activating and resistance mutations of EGFR in non-small-cell lung cancer: Role in clinical response to EGFR tyrosine kinase inhibitors. Oncogene. 2009, 28 (Suppl. 1), S24-S31. [CrossRef]

40. Choi, J.; Majima, T. Conformational changes of non-B DNA. Chem. Soc. Rev. 2011, 40, 5893-5909. [CrossRef]

41. Zhao, J.; Bacolla, A.; Wang, G.; Vasquez, K.M. Non-B DNA structure-induced genetic instability and evolution. Cell. Mol. Life Sci. 2010, 67, 43-62. [CrossRef]

42. Bochman, M.L.; Paeschke, K.; Zakian, V.A. DNA secondary structures: Stability and function of G-quadruplex structures. Nat. Rev. Genet. 2012, 13, 770-780. [CrossRef]

43. Balasubramanian, S.; Hurley, L.H.; Neidle, S. Targeting G-quadruplexes in gene promoters: A novel anticancer strategy? Nat. Rev. Drug Discov. 2011, 10, 261-275. [CrossRef] [PubMed]

44. Cogoi, S.; Zorzet, S.; Rapozzi, V.; Géci, I.; Pedersen, E.B.; Xodo, L.E. MAZ-binding G4-decoy with locked nucleic acid and twisted intercalating nucleic acid modifications suppresses KRAS in pancreatic cancer cells and delays tumor growth in mice. Nucleic Acids Res. 2013, 41, 4049-4064. [CrossRef]

45. Adams, J.M. The Bcl-2 Protein Family: Arbiters of Cell Survival. Science 1998, 281, 1322-1326. [CrossRef]

46. Yip, K.W.; Reed, J.C. Bcl-2 family proteins and cancer. Oncogene 2008, 27, 6398-6406. [CrossRef] [PubMed]

47. Asamitsu, S.; Obata, S.; Yu, Z.; Bando, T.; Sugiyama, H. Recent Progress of Targeted G-Quadruplex-Preferred Ligands Toward Cancer Therapy. Molecules 2019, 24, 429. [CrossRef]

48. Ghosh, S. Cisplatin: The first metal based anticancer drug. Bioorg. Chem. 2019, 88, 102925. [CrossRef]

49. Gue'rin, O.; Fischel, J.L.; Ferrero, J.M.; Bozec, A.; Milano, G. EGFR targeting in hormone-refractory prostate cancer: Current appraisal and prospects for treatment. Pharmaceuticals 2010, 3, 2238-2247. [CrossRef] [PubMed]

50. Abdelgawad, M.A.; Bakr, R.B.; Alkhoja, O.A.; Mohamed, W.R. Design, synthesis and antitumor activity of novel pyrazolo[3,4d]pyrimidine derivatives as EGFR-TK inhibitors. Bioorg. Chem. 2016, 66, 88-96. [CrossRef]

51. Holbro, T.; Hynes, N.E. ErbB receptors: Directing key signaling networks throughout life. Annu. Rev. Pharmacol. Toxicol. 2004, 44, 195-217. [CrossRef] [PubMed]

52. Ducray, R.; Ballard, P.; Barlaam, B.C.; Hickinson, M.D.; Kettle, J.G.; Ogilvie, D.J.; Trigwell, C.B. Novel 3-alkoxy-1H-pyrazolo[3,4d]pyrimidines as EGFR and erbB2 receptor tyrosine kinase inhibitors. Bioorg. Med. Chem. Lett. 2008, 18, 959-962. [CrossRef]

53. Bakr, R.B.; Mehany, A.B.M.; Abdellatif, K.R.A. Synthesis, EGFR Inhibition and Anti-cancer Activity of New 3,6-dimethyl-1phenyl-4-(substituted-methoxy)pyrazolo[3,4-d] pyrimidine Derivatives. Anticancer Agents Med. Chem. 2017, 17, 1389-1400. [CrossRef] [PubMed]

54. Abbas, S.E.; Aly, E.I.; Awadallah, F.M.; Mahmoud, W.R. 4-Substituted-1-phenyl-1H-pyrazolo[3,4-d]pyrimidine derivatives: Design, synthesis, antitumor and EGFR tyrosine kinase inhibitory activity. Chem. Biol. Drug Des. 2015, 85, 608-622. [CrossRef] [PubMed]

55. Ouyang, L.; Chen, Y.; Wang, X.Y.; Lu, R.F.; Zhang, S.Y.; Tian, M.; Xie, T.; Liu, B.; He, G. Polygonatum odoratum lectin induces apoptosis and autophagy via targeting EGFR-mediated Ras-Raf-MEK-ERK pathway in human MCF-7 breast cancer cells. Phytomedicine 2014, 21, 1658-1665. [CrossRef] [PubMed]

56. Balakrishnan, S.; Mukherjee, S.; Das, S.; Bhat, F.A.; Raja Singh, P.; Patra, C.R.; Arunakaran, J. Gold nanoparticles-conjugated quercetin induces apoptosis via inhibition of EGFR/PI3K/Akt-mediated pathway in breast cancer cell lines (MCF-7 and MDAMB-231). Cell Biochem. Funct. 2017, 35, 217-231. [CrossRef]

57. Moiseeva, E.P.; Heukers, R.; Manson, M.M. EGFR and Src are involved in indole-3-carbinol-induced death and cell cycle arrest of human breast cancer cells. Carcinogenesis 2007, 28, 435-445. [CrossRef] 
58. Mahernia, S.; Hassanzadeh, M.; Sharifi, N.; Mehravi, B.; Paytam, F.; Adib, M.; Amanlou, M. Structure-based pharmacophore design and virtual screening for novel potential inhibitors of epidermal growth factor receptor as an approach to breast cancer chemotherapy. Mol. Divers. 2018, 22, 173-181. [CrossRef]

59. Singh, P.; Bast, F. In silico molecular docking study of natural compounds on wild and mutated epidermal growth factor receptor. Med. Chem. Res. 2014, 23, 5074-5085. [CrossRef]

60. Ayaz, M.; Sadiq, A.; Wadood, A.; Junaid, M.; Ullah, F.; Khan, N.Z. Cytotoxicity and molecular docking studies on Phytosterols isolated from Polygonum hydropiper L. Steroids 2018, 141, 30-35. [CrossRef]

61. Huether, A.; Höpfner, M.; Sutter, A.P.; Schuppan, D.; Scherübl, H. Erlotinib induces cell cycle arrest and apoptosis in hepatocellular cancer cells and enhances chemosensitivity towards cytostatics. J. Hepatol. 2005, 43, 661-669. [CrossRef]

62. Shan, F.; Shao, Z.; Jiang, S.; Cheng, Z. Erlotinib induces the human non-small-cell lung cancer cells apoptosis via activating ROS-dependent JNK pathways. Cancer Med. 2016, 5, 3166-3175. [CrossRef]

63. Saleh, M.M.; Laughton, C.A.; Bradshaw, T.D.; Moody, C.J. Development of a series of bis-triazoles as G-quadruplex ligands. RSC Adv. 2017, 7, 47297-47308. [CrossRef]

64. Horchani, M.; Hajlaoui, A.; Harrath, A.H.; Mansour, L.; Ben Jannet, H.; Romdhane, A. New pyrazolo-triazolo-pyrimidine derivatives as antibacterial agents: Design and synthesis, molecular docking and DFT studies. J. Mol. Struct. 2020, 1199, 127007. [CrossRef]

65. Lopes, A.B.; Miguez, E.; Kümmerle, A.E.; Rumjanek, V.M.; Fraga, C.A.; Barreiro, E.J. Characterization of amide bond conformers for a novel heterocyclic template of N-acylhydrazone derivatives. Molecules 2013, 18, 11683-11704. [CrossRef]

66. Patorski, P.; Wyrzykiewicz, E.; Bartkowiak, G. Synthesis and conformational assignment of N-(E)-stilbenyloxymethylenecarbonylsubstituted hydrazones of acetone and o- (m-and p-) chloro- (nitro-) benzaldehydes by means of and NMR spectroscopy. J. Spectrosc. 2013, 1-12. [CrossRef]

67. Teta, R.; Della Sala, G.; Esposito, G.; Via, C.W.; Mazzoccoli, C.; Piccoli, C.; Bertin, M.J.; Costantino, V.; Mangoni, A. A joint molecular networking study of a Smenospongia sponge and a cyanobacterial bloom revealed new antiproliferative chlorinated polyketides. Org. Chem. Front. 2019, 6, 1762-1774. [CrossRef] [PubMed]

68. Imperatore, C.; Della Sala, G.; Casertano, M.; Luciano, P.; Aiello, A.; Laurenzana, I.; Piccoli, C.; Menna, M. In Vitro Antiproliferative Evaluation of Synthetic Meroterpenes Inspired by Marine Natural Products. Mar. Drugs 2019, 17, 684. [CrossRef] [PubMed]

69. Frisch, M.J.; Trucks, G.W.; Schlegel, H.B.; Scuseria, G.E.; Robb, M.A.; Cheeseman, J.R.; Scalmani, G.; Barone, V.; Petersson, G.A.; Nakatsuji, H.; et al. Gaussian 09; Gaussian, Inc.: Wallingford, CT, USA, 2010.

70. Stamos, J.; Sliwkowski, M.X.; Eigenbrot, C. Structure of the epidermal growth factor receptor kinase domain alone and in complex with a 4-anilinoquinazoline inhibitor. J. Biol. Chem. 2002, 277, 46265-46272. [CrossRef]

71. AutoDock-Scripps Research. Available online: http:/ / autodock.scripps.edu/ (accessed on 15 January 2021).

72. The PyMOL Molecular Graphics System, Version 1.5.0.4; Schrödinger, LLC.: New York, NY, USA, 2015.

73. Oliviero, G.; Errico, S.D.; Borbone, N.; Amato, J.; Piccialli, V.; Varra, M.; Piccialli, G.; Mayol, L. A solid-phase approach to the synthesis of N -1-alkyl analogues of cyclic inosine-diphosphate-ribose (cIDPR). Tetrahedron 2010, 66, 1931-1936. [CrossRef]

74. Cantor, C.R.; Warshaw, M.M.; Shapiro, H. Oligonucleotide interactions. III. Circular dichroism studies of the conformation of deoxyoligonucleolides. Biopolymers 1970, 9, 1059-1077. [CrossRef] 